\title{
Impact of climate change on tropospheric ozone and its global budgets
}

\author{
G. Zeng, J. A. Pyle, and P. J. Young \\ National Centre for Atmospheric Science, Department of Chemistry, University of Cambridge, Cambridge, UK
}

Received: 20 July 2007 - Published in Atmos. Chem. Phys. Discuss.: 27 July 2007

Revised: 27 November 2007 - Accepted: 17 December 2007 - Published: 29 January 2008

\begin{abstract}
We present the chemistry-climate model UM_CAM in which a relatively detailed tropospheric chemical module has been incorporated into the UK Met Office's Unified Model version 4.5. We obtain good agreements between the modelled ozone/nitrogen species and a range of observations including surface ozone measurements, ozone sonde data, and some aircraft campaigns.
\end{abstract}

Four 2100 calculations assess model responses to projected changes of anthropogenic emissions (SRES A2), climate change (due to doubling $\mathrm{CO}_{2}$ ), and idealised climate change-associated changes in biogenic emissions (i.e. $50 \%$ increase of isoprene emission and doubling emissions of soil$\mathrm{NO}_{\mathrm{x}}$ ). The global tropospheric ozone burden increases significantly for all the 2100 A2 simulations, with the largest response caused by the increase of anthropogenic emissions. Climate change has diverse impacts on $\mathrm{O}_{3}$ and its budgets through changes in circulation and meteorological variables. Increased water vapour causes a substantial ozone reduction especially in the tropical lower troposphere ( $>10 \mathrm{ppbv}$ reduction over the tropical ocean). On the other hand, an enhanced stratosphere-troposphere exchange of ozone, which increases by $80 \%$ due to doubling $\mathrm{CO}_{2}$, contributes to ozone increases in the extratropical free troposphere which subsequently propagate to the surface. Projected higher temperatures favour ozone chemical production and PAN decomposition which lead to high surface ozone levels in certain regions. Enhanced convection transports ozone precursors more rapidly out of the boundary layer resulting in an increase of ozone production in the free troposphere. Lightning-produced $\mathrm{NO}_{\mathrm{x}}$ increases by about $22 \%$ in the doubled $\mathrm{CO}_{2}$ climate and contributes to ozone production.

The response to the increase of isoprene emissions shows that the change of ozone is largely determined by background $\mathrm{NO}_{\mathrm{x}}$ levels: high $\mathrm{NO}_{\mathrm{x}}$ environment increases ozone produc-

Correspondence to: G. Zeng

(guang.zeng@atm.ch.cam.ac.uk) tion; isoprene emitting regions with low $\mathrm{NO}_{\mathrm{x}}$ levels see local ozone decreases, and increase of ozone levels in the remote region due to the influence of PAN chemistry. The calculated ozone changes in response to a $50 \%$ increase of isoprene emissions are in the range of between $-8 \mathrm{ppbv}$ to 6 ppbv. Doubling soil- $\mathrm{NO}_{\mathrm{x}}$ emissions will increase tropospheric ozone considerably, with up to 5 ppbv in source regions.

\section{Introduction}

Tropospheric ozone $\left(\mathrm{O}_{3}\right)$ has important chemical and radiative roles and has been a focus of many modelling studies. It can be a regional pollutant; high levels of ozone are harmful to human health and vegetation. $\mathrm{O}_{3}$ is the primary source of the hydroxyl radical $(\mathrm{OH})$, which plays a key role in the oxidizing capacity of the atmosphere. It is also important because of its radiative impact; ozone is currently the third most important greenhouse gas after carbon dioxide $\left(\mathrm{CO}_{2}\right)$ and methane $\left(\mathrm{CH}_{4}\right)$.

During the industrial era, human activities have changed the chemical composition of the atmosphere considerably. Increasing surface emissions of methane, carbon monoxide (CO), volatile organic compounds (VOCs) and nitrogen oxides $\left(\mathrm{NO}_{\mathrm{x}}=\mathrm{NO}+\mathrm{NO}_{2}\right)$, produced by biomass burning and fossil-fuel combustion, have caused tropospheric $\mathrm{O}_{3}$ concentrations to increase significantly (Volz and Kley, 1988; Thompson, 1992; Marenco et al., 1994). The total amount of tropospheric $\mathrm{O}_{3}$ is estimated to have increased by $30 \%$ globally since 1750 , which corresponds to an average positive radiative forcing of $0.35 \mathrm{Wm}^{-2}$ (Houghton et al., 2001). Further increases of tropospheric $\mathrm{O}_{3}$ are anticipated in response to continuing increases in surface emissions.

Tropospheric ozone is formed as a secondary photochemical product of the oxidation of $\mathrm{CO}$ and hydrocarbons in the presence of $\mathrm{NO}_{\mathrm{x}}$. Its short chemical lifetime results in an

Published by Copernicus Publications on behalf of the European Geosciences Union. 
inhomogeneous distribution and a stronger dependence on changes in source gas emissions than for longer-lived greenhouse gases. The complex $\mathrm{O}_{3}$ chemistry in the troposphere requires a comprehensive chemical mechanism describing $\mathrm{NO}_{\mathrm{x}} / \mathrm{VOC}$ chemistry to be incorporated in a 3-dimensional chemistry/climate model to simulate the global $\mathrm{O}_{3}$ distribution and to assess climate feedbacks.

Numerous studies of the evolution of tropospheric $\mathrm{O}_{3}$ changes since preindustrial times and the associated radiative forcings have been carried out using various chemical transport or climate models (e.g., Hauglustaine et al., 1994; Forster et al., 1996; Roelofs et al., 1997; Berntsen et al., 2000; Brasseur et al., 1998; Stevenson et al., 1998a; Mickley et al., 1999; Hauglustaine and Brasseur, 2001; Grenfell et al., 2001). However there is often significant difference between models in their predictions of ozone change, (see, e.g. Houghton et al., 2001), even though these models normally reproduce present-day observations "satisfactorily". Future changes of tropospheric $\mathrm{O}_{3}$ will depend on how the emissions of ozone precursors change in the future and also on how the climate will change. Continuing emissions of $\mathrm{NO}_{\mathrm{x}}$ and VOCs are predicted to increase tropospheric $\mathrm{O}_{3}$, but the anticipated rise in temperature and humidity will likewise have an impact. A number of studies have suggested that an anticipated warmer and wetter climate would slow down the increase in $\mathrm{O}_{3}$ abundance compared to an unchanged climate (Brasseur et al., 1998; Johnson et al., 1999; Stevenson et al., 2000).

We have reported earlier studies with a tropospheric chemical module (identical to the off-line CTM TOMCAT, see Law et al., 1998) incorporated into the UK Met Office (UKMO) Unified Model (UM) version 4.4. The chemistry comprised $\mathrm{NO}_{\mathrm{x}} / \mathrm{CO} / \mathrm{CH}_{4} / \mathrm{NMVOCs}\left(\mathrm{C}_{2}-\mathrm{C}_{3}\right.$ alkanes, $\mathrm{HCHO}$, $\mathrm{CH}_{3} \mathrm{CHO}$ and Acetone). The model was used to assess tropospheric ozone changes between 2000 and 2100 using the SRES A2 scenario (Zeng and Pyle, 2003). We assessed the feedback on chemical ozone production following increased water vapour, but, in contrast to some of the earlier studies, found that large-scale dynamical changes in a future climate led to an increase in tropospheric ozone through enhanced stratosphere-troposphere exchange (Zeng and Pyle, 2003). An increased STE in a future climate was also reported by Collins et al. (2003) and Sudo et al. (2003). However detailed studies on the feedbacks between climate change and tropospheric composition are still limited. Stevenson et al. (2005) discuss the impact of changes in physical climate on tropospheric chemical composition; the climate feedbacks are dominantly negative (e.g. reduced tropospheric ozone burden and lifetime, and shortened methane lifetime), but more modelling studies are needed in order to reach a common consensus on climate feedbacks. Most recently, Stevenson et al. (2006) reported an ensemble modelling study from 25 models for the 4th IPCC assessment. Simulations for the assessment contrasted a 2000 atmosphere with the year 2030, including runs with changed precursor emissions only, and a run considering both the changes of emissions and climate. The model-model differences are largest when the climate change scenario is considered. In addition, some recent regional and global model studies indicate substantial regional impacts of climate change on concentrations of surface ozone (Langner et al., 2005; Murazaki and Hess, 2006).

It is likely that climate change will also affect emissions of trace gases from the biosphere. Isoprene is an reactive biogenic compound, emitted by several plant species and with a global source comparable to methane (Guenther et al., 1995). Isoprene emission is sensitive to temperature (e.g., Monson and Fall, 1989; Sharkey et al., 1996), $\mathrm{CO}_{2}$ concentration (Rosenstiel et al., 2003) and water availability (Pegoraro et al., 2005), amongst other factors. These driving variables are expected to change in the future, hence there has been some interest in projecting future isoprene emissions and quantifying their effect on atmospheric composition (Sanderson et al., 2003; Hauglustaine et al., 2005; Wiedinmyer et al., 2006). Estimates of the emission at the end of the 21 st century range from 640 to $890 \mathrm{TgC} / \mathrm{yr}$ (Sanderson et al., 2003; Lathiere et al., 2005; Wiedinmyer et al., 2006), with the biggest driver being the projected increase in surface temperature. Changes in the emission of $\mathrm{NO}_{\mathrm{x}}$ by microorganisms in soils is another important climate-biosphere feedback, due to the importance of $\mathrm{NO}_{\mathrm{x}}$ in tropospheric photochemistry. These emissions are expected to increase in a warmer, wetter atmosphere (Yienger and Levy, 1995).

In this paper, we present the results from a version of our chemistry-climate model (UM_CAM) updated to include an isoprene oxidation scheme. We calculate ozone changes for a 2100 climate with associated chemical and dynamical changes (e.g. ozone production/destruction, stratospheretroposphere exchange). We chose the SRES A2 scenario for the year 2100, which predicts relatively large emission increases, in order to explore a large range of influences on future air quality. Currently, there are large uncertainties in the estimation of biogenic emissions. Here, we carry out an initial assessment of the impact of idealised increases in isoprene emissions and altered soil- $\mathrm{NO}_{\mathrm{x}}$ emissions on future tropospheric ozone. A paper by Young et al. $(2008)^{1}$ will discuss in detail the role of isoprene on ozone formation.

The base climate model is the UM version 4.5. We describe the model in Sect. 2. In Sect. 3 the experimental setup is given. In Sect. 4, we present the present-day simulation and compare modelled $\mathrm{O}_{3}, \mathrm{NO}_{\mathrm{x}}$ and PAN to observations. Section 5 presents future simulations: impacts on tropospheric $\mathrm{O}_{3}$ from the anthropogenic emissions and from changes in meteorology are discussed; idealised changes in the biogenic emission, related to climate change, are also assessed. The tropospheric ozone budgets for the various cases

\footnotetext{
${ }^{1}$ Young, P. J., Zeng, G., and Pyle, J. A.: The ineractions and tropospheric impacts of changes in anthropogenic emissions, biogenic isoprene emissions and climate modelled for a 2100 atmosphere, in preparation, 2008.
} 
Table 1. Simulations.

\begin{tabular}{|c|c|c|c|}
\hline Simulations & Emissions & Meteorology & Description \\
\hline Run A & IIASA-2000 & $2000 \mathrm{~s}$ & Present-day \\
\hline Run B & A2-2100 & $2000 \mathrm{~s}$ & Future (A+ $+\Delta$ anthropogenic emissions) \\
\hline Run C & A2-2100 & $2100 \mathrm{~s}$ & Future ( $\mathrm{B}+$ climate change) \\
\hline Run D & A2-2100+ $\Delta$ isoprene & $2100 \mathrm{~s}$ & Future $(\mathrm{C}+\Delta$ isoprene emissions $)$ \\
\hline Run E & $\mathrm{A} 2-2100+\Delta$ soil- $\mathrm{NO}_{\mathrm{X}}$ & $2100 \mathrm{~s}$ & Future $\left(\mathrm{C}+\Delta\right.$ soil- $\mathrm{NO}_{\mathrm{X}}$ emissions $)$ \\
\hline
\end{tabular}

in Sects. 4 and 5 are analysed. Conclusions are gathered in Sect. 6.

\section{Model description}

\subsection{Climate model}

The UM is developed and used at the UKMO for weather prediction and climate research (Cullen, 1993; Senior and Mitchell, 2000; Johns et al., 2003). Here we use the 19 level UM version 4.5. It uses a hybrid sigma-pressure vertical coordinate, and the model domain extends from the surface up to $4.6 \mathrm{hPa}$. The horizontal resolution is $3.75^{\circ}$ by $2.5^{\circ}$. The model's meteorology is forced using prescribed sea surface temperatures (SSTs).

We adopt an improved tracer advection scheme (A. R. Gregory, private communication, 2001) to replace the existing scheme in the UM which is based on Roe's flux redistribution method (Roe, 1985). The Roe scheme has the advantage of being a monotonic method but suffers from low accuracy at the climate resolution used here. The new tracer transport scheme is based on the 1D NIRVANA scheme of Leonard et al. (1995) using the same extension to $3 \mathrm{D} /$ sphere as the Roe scheme. The new scheme is conservative, monotonic and more accurate than the Roe scheme at a lesser computational cost. It is considerably less diffusive in the vertical than the Roe scheme.

Convection is parameterized by a penetrative mass flux scheme (Gregory and Rowntree, 1990) in which buoyant parcels are modified by entrainment and detrainment to represent an ensemble of convective clouds. The convection scheme has been tested using ${ }^{222} \mathrm{Rn}$ experiments; the agreement with observations is reasonable (Stevenson et al., 1998b).

The Edwards and Slingo (1996) radiation code is used in the UM. Absorption by water vapour, carbon dioxide and $\mathrm{O}_{3}$ are included in both longwave and shortwave calculations. Absorption by methane, nitrous oxide, CFC- 11 and CFC-12 are also included in the longwave scheme. Water vapour is a basic model variable. Prescribed monthly zonal mean $\mathrm{O}_{3}$ climatology fields are used in the radiation scheme unless otherwise stated. Mixing ratios of other gases are assumed to be global constants.

\subsection{Chemical module}

The tropospheric chemical mechanism includes $\mathrm{CO}$, methane and NMVOC oxidation as previously used in the off-line transport model TOMCAT (Law et al., 1998) and earlier versions of the UM+chemistry model (Zeng and Pyle, 2003, 2005). An isoprene oxidation scheme adopted from Pöschl et al. (2000) was recently added into the model (see Young, 2007 for more details). Reaction rates are taken from the recent IUPAC (Atkinson et al., 1999) and JPL (DeMore et al., 1997) evaluations. Chemical integrations are performed using an implicit time integration scheme, IMPACT (Carver and Stott, 2000), with a 15 min time step. The model includes 60 species and 174 chemical reactions. Two tracers, $\mathrm{O}_{x}$ and $\mathrm{NO}_{\mathrm{x}}$, are treated as chemical families. $\mathrm{OH}, \mathrm{HO}_{2}$ and other short-lived peroxy radicals are assumed to be in steady state. The model uses the diurnal varying photolysis rates calculated off-line in a 2-D model (Law and Pyle, 1993) and interpolated to 3-D fields. Note that the effect of changes in cloudiness is not included. Loss of trace species by dry deposition is included using deposition velocities which are calculated using prescribed deposition velocities at $1 \mathrm{~m}$ height (largely taken from Valentin, 1990 and Zhang et al., 2003), depending on season, time of the day and on the type of surface (grass, forest, dessert, water, snow/ice) and are extrapolated to the middle of the lowest model layer using a formula described by Sorteberg and Hov (1996). Wet deposition of soluble species is represented as a first order loss using model-calculated large-scale and convective rainfall rates. A detailed description of the dry and wet deposition schemes is given by Giannakopoulos et al. (1999). Instead of explicit stratospheric chemistry in the model, daily concentrations of $\mathrm{O}_{3}, \mathrm{NO}_{\mathrm{y}}$ and $\mathrm{CH}_{4}$ are prescribed at the top three model layers (29.6, 14.8 and $4.6 \mathrm{hPa})$ using output from the 2-D model, to produce a realistic annual cycle of these species in the stratosphere. Note that the scheme includes the important stratospheric $\mathrm{NO}_{\mathrm{x}} / \mathrm{HO}_{\mathrm{x}}$ chemistry and is applied in the lowermost stratosphere (i.e. below $30 \mathrm{hPa}$ ) but that no halogen chemistry is included.

\section{Experimental setup}

We have performed 5 simulations (see Table 1). In all runs the meteorology is calculated on-line using specified sea sur- 
face temperatures for the simulation period considered here. The baseline run A covers the years 1996-2000 using emissions for year 2000 and is used to verify the model performance against observations. Run B uses 2100 emissions to assess changes of tropospheric composition only due to changes in these anthropogenic emissions. Run C calculates future changes due to changes in both anthropogenic emissions and the climate using 2100 emissions (same as run B) and a double $\mathrm{CO}_{2}$ climate forcing with appropriate SSTs for that period. In runs $\mathrm{B}$ and $\mathrm{C}$ biogenic emissions are held constant. Run D is based on run C but uses elevated isoprene emissions to assess the sensitivity of the model to increased biogenic emissions which may be associated with climate change. Similar to run $\mathrm{C}$, run $\mathrm{E}$ also accounts for increased soil $\mathrm{NO}_{\mathrm{x}}$ emissions in addition to the anthropogenic emissions. We performed multiyear simulations for all the scenarios and data are averaged over all years. Specifically, we run base scenario A for 5 years to evaluate the model performance against the observations. Runs $\mathrm{B}$ and $\mathrm{C}$ are also for 5 years to minimize the effects of interannual variability, which is particularly crucial for isolating the impact of climate change. Multiyear runs are not considered essential for assessing the emission changes only. However we did perform 3 year runs for both $\mathrm{D}$ and $\mathrm{E}$, and compare the averaged results with run $\mathrm{C}$ averaged for the same period.

We use observed monthly mean sea surface temperature and sea ice climatology compiled at the Hadley centre (GISST 2.0) to drive the present-day climate. The future climate is driven by SSTs produced by the Hadley Centre coupled ocean-atmosphere GCM (HadCM3) run with IS92a emissions for the year 2090-2100 (i.e. doubled $\mathrm{CO}_{2}$ ) (Johns et al., 2003; Cox et al., 2004). In the radiation scheme, the same present-day $\mathrm{O}_{3}$ climatology from $\mathrm{Li}$ and Shine (1995) is used for all model runs; other trace gases mixing ratios are fixed at present-day levels with only $\mathrm{CO}_{2}$ doubled in the future climate runs.

Emissions are seasonally varying but have no inter-annual variability except for $\mathrm{NO}_{\mathrm{x}}$ produced from lightning which is climate-dependent. In detail, the anthropogenic emissions of $\mathrm{NO}_{\mathrm{x}}, \mathrm{CO}$ and NMVOCs for the present-day are from the recently published emission scenarios by the International Institute of Applied System Analysis (IIASA) which was described in detail by Dentener et al. (2005) and references therein. Anthropogenic emissions appropriate to 2100 are based on the IPCC Special Report on Emission Scenarios (SRES) for the year 2100 (Nakićenović et al., 2000). We chose the A2 scenario to demonstrate the sensitivity to assumed large emission changes.

We include $512 \mathrm{TgC} / \mathrm{yr}$ total annual emissions of isoprene (Guenther et al., 1995) in the base run. For run D, isoprene emissions are increased by $50 \%$ relative to the base run $(768 \mathrm{TgC} / \mathrm{yr})$. This increased isoprene emission sits roughly in the middle of the 2100 estimates of Sanderson et al. (2003), Lathiere et al. (2005), and Wiedinmyer et al. (2006) $(640-890 \mathrm{TgC} / \mathrm{yr})$ although, unlike their experi- ments, we do not account for any change in the distribution of the vegetation and simply scale up the present day emissions. Run D is used to assess the sensitivity of the modelled 2100 atmosphere to an increase in isoprene emission, rather than be a prediction of future isoprene emissions.

Large uncertainties exist in estimating the global soilbiogenic $\mathrm{NO}_{\mathrm{x}}$ emissions. In our base run, we take the data from Yienger and Levy (1995) and scale to $7 \mathrm{TgN} / \mathrm{yr}$ which is close to the upper end of their estimation for the 1990s. Yienger and Levy (1995) related soil- $\mathrm{NO}_{\mathrm{x}}$ emissions to biome, soil temperature, precipitation and fertilizer application. They estimated a $25 \%$ increase from 1990 to 2025 in response to a warmer, wetter climate. In our soil- $\mathrm{NO}_{\mathrm{x}}$ perturbation run $\mathrm{E}$, we simply double the present-day value to develop a scaled emission field appropriate for a 2100 atmosphere sensitivity experiment.

For all the runs, other natural emissions are kept the same as in 2000 and are taken from the EDGAR3.2 global emission inventory (Olivier and Berdowski, 2001). Biomass burning is based on the Global Fire Emission Data averaged for 1997-2002 (van der Werf et al., 2003). Lightningproduced $\mathrm{NO}_{\mathrm{x}}$ is calculated as a function of the cloud top height using the parameterization of Price and Rind (1992, 1994) and scaled close to $4 \operatorname{Tg}(\mathrm{N}) \mathrm{yr}^{-1}$ for the present day simulation. For the simulation with the future climate forcing, a $22 \%$ increase of lightning- $\mathrm{NO}_{\mathrm{x}}$ emissions was found as a result of the increase in convection in a warmer and wetter climate. A summary of the emissions is given in Table 2. Methane concentrations are constrained throughout the model domain to reduce the spin-up time and eliminate possible trends. Prescribed stratospheric $\mathrm{O}_{3}$ and $\mathrm{NO}_{\mathrm{y}}$, and photolysis rates are kept the same for all model runs.

\section{Present-day simulation}

\subsection{Ozone}

Figure 1 shows modelled monthly mean distributions of surface $\mathrm{O}_{3}$ for January, April, July and October. The broad features agree well with observations. Surface $\mathrm{O}_{3}$ is generally higher in the $\mathrm{NH}$ than in the $\mathrm{SH}$ due to the higher emissions of ozone precursors there. Seasonally, the highest surface $\mathrm{O}_{3}$ level occurs in July due to intensified photochemical production of $\mathrm{O}_{3}$, while in winter the $\mathrm{O}_{3}$ level is generally low with higher values over the ocean.

We have compared the baseline simulation with a wide range of long term observations. Figure 2 shows the simulated and observed monthly mean $\mathrm{O}_{3}$ concentrations near the surface. The observational data are from the World Data Centre for Surface Ozone (WDSO) (http://gaw.kishou.go. jp/wdcgg.html), with major contributions from CMDL. We have selected stations with data covering the years 19962004 where possible. The ozone concentrations from the simulation are averaged over 1996-2000. Most of the obser- 

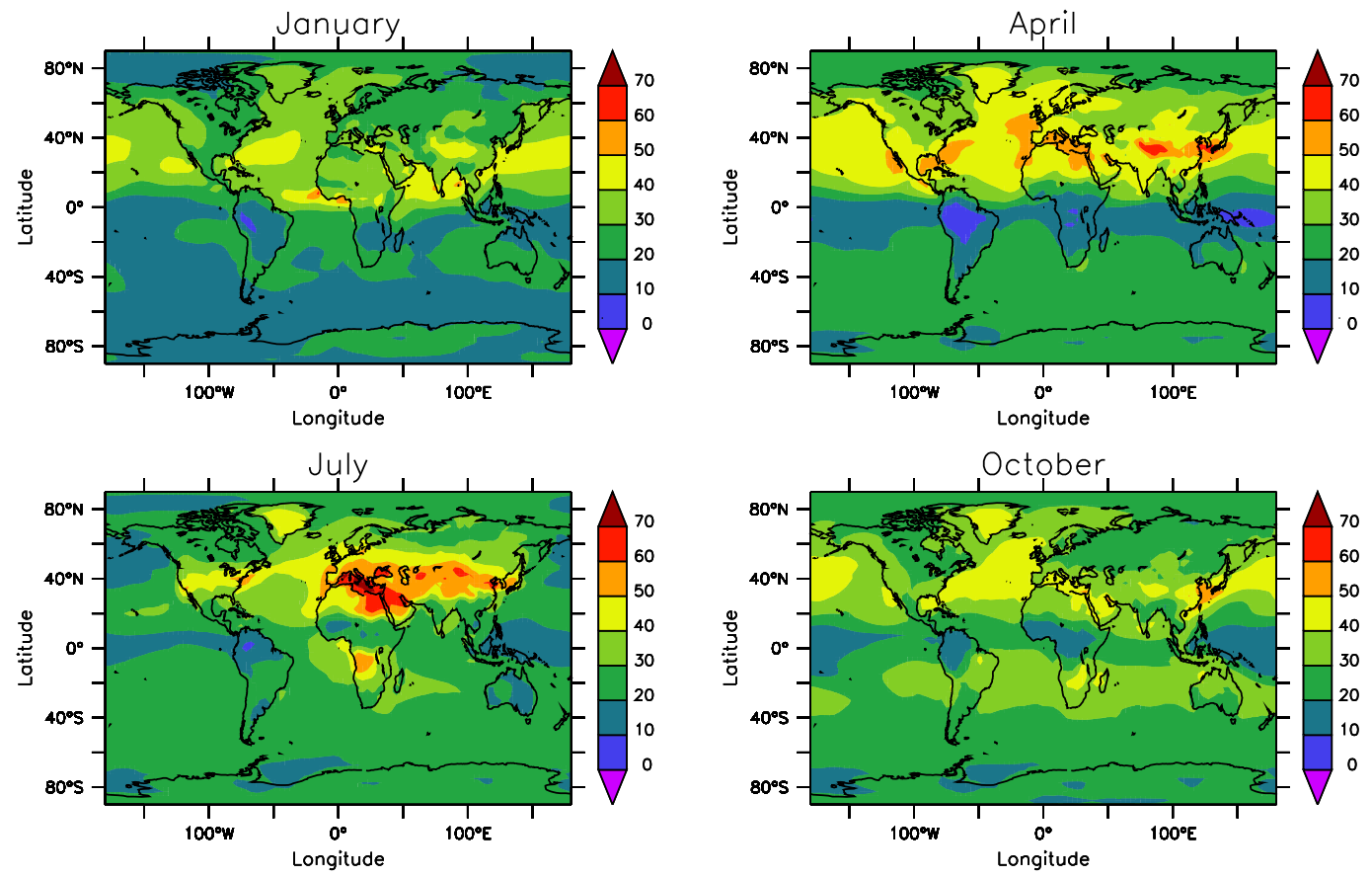

Fig. 1. Modelled surface $\mathrm{O}_{3}$ (ppbv) in January, April, July and October from the present-day simulation.

Table 2. Summary of annual total emissions.

\begin{tabular}{llllll}
\hline & IIASA-2000 & A2-2100 (B) & A2-2100 (C) & A2-2100 (D) & A2-2100 (E) \\
CO (Tg CO) & & & & & \\
Fossil fuel & 470 & 1720 & 1720 & 1720 & 1720 \\
Biomass burning & 507 & 507 & 507 & 507 & 507 \\
Ocean/vegetation & 100 & 100 & 100 & 100 & 100 \\
\hline $\mathrm{NO}_{\mathrm{x}}\left(\mathrm{Tg} \mathrm{NO} \mathrm{NO}_{2}\right)$ & & & & \\
Fossil fuel & 91.4 & 333 & 333 & 333 & 333 \\
Biomass burning & 33.4 & 33.4 & 33.4 & 33.4 & 33.4 \\
Soil & 23 & 23 & 23 & 23 & 46 \\
Aircraft & 2.58 & 5.67 & 5.67 & 5.67 & 5.67 \\
Lightning & 10.3 & 10.3 & 12.6 & 12.6 & 12.6 \\
\hline NMVOCs (Tg VOC) & & & & & \\
Industrial source & 116 & 306 & 306 & 306 & 306 \\
Biomass burning & 31.2 & 31.2 & 31.2 & 31.2 & 31.2 \\
Natural (isoprene) & 580 & 580 & 580 & 870 & 580 \\
\hline CH (ppbv) & 1760 & 3731 & 3731 & 3731 & 3731 \\
\hline
\end{tabular}

vations are well reproduced by the model. For the northernhemisphere extratropical remote sites, the observations are characterized by a spring maximum and a summer minimum associated with relatively strong downward flux of $\mathrm{O}_{3}$ from the stratosphere in the spring and efficient photochemical destruction in summer. A summer maximum over polluted continental areas (e.g. at Hohenpeissenberg) associated with intensified photochemical production is well reproduced by the model. There are some discrepancies between the model and the measurements. At Barrow, the observed spring minimum in surface $\mathrm{O}_{3}$ may well be associated with bromine chemistry (Barrie et al., 1988) which is not represented in the model. The observed summer minima at Ryori and Bermuda are weak in the model simulation. At the southern tropical sites, the observations indicate an austral spring maximum which is well captured by the model. The year-round low $\mathrm{O}_{3}$ value 

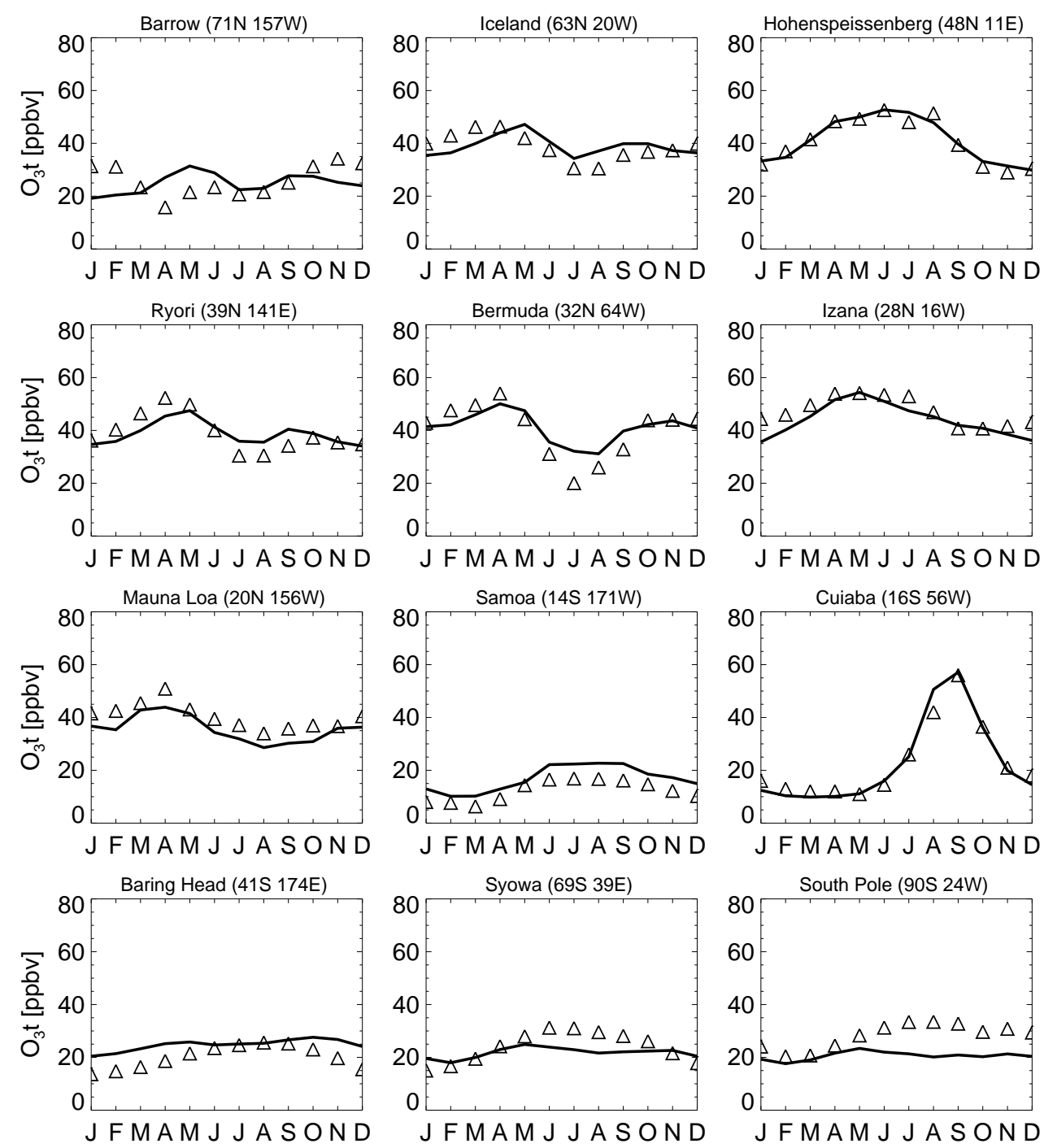

Fig. 2. Observed (symbols) and simulated (lines) surface ozone (ppbv). Data from the World Data Centre for Surface Ozone (see text).

in Samoa is well simulated. The austral spring maxima at Cuiaba, produced by biomass burning, is also accurately reproduced. The observed surface $\mathrm{O}_{3}$ concentrations at southern middle and high latitudes shows a winter maximum and a summer minimum in the lower troposphere. This feature is not well simulated by the model. The seasonal cycle produced by the model is relatively weak and does not reflect that of the measurements. The model over-estimates summer $\mathrm{O}_{3}$ concentrations in Baring Head and also underestimates $\mathrm{O}_{3}$ values by up to $20 \mathrm{ppbv}$ in the austral winter-spring over Antarctica. The cause of these discrepancies needs to be investigated further.

We have also compared the modelled vertical ozone concentrations to $\mathrm{O}_{3}$ sonde measurements (Logan, 1999) made between 1985-1995 (Fig. 3). Note that the ozone concentrations from the baseline simulation are averaged over 1996-
2000. The model simulation agrees reasonably well with the observations. The model captures very well the strong vertical $\mathrm{O}_{3}$ concentration gradient shown in the measurements in middle to high latitudes in both hemispheres. The mid tropospheric maxima in the northern subtropical sites at Kagoshima and Hilo are well simulated by the model. In the southern tropical site Samoa, the model simulates the steep decrease of $\mathrm{O}_{3}$ concentrations in the lower troposphere but underestimates the elevated $\mathrm{O}_{3}$ concentrations in the middle and upper troposphere, especially in Natal (not shown), indicating possibly that there is not enough convective lifting of $\mathrm{O}_{3}$ and its precursors to the middle and upper troposphere during the biomass burning season.

In general the model does a good job in simulating observed $\mathrm{O}_{3}$. However, to understand factors affecting $\mathrm{O}_{3}$ it is necessary also to look at the processes involved in ozone 

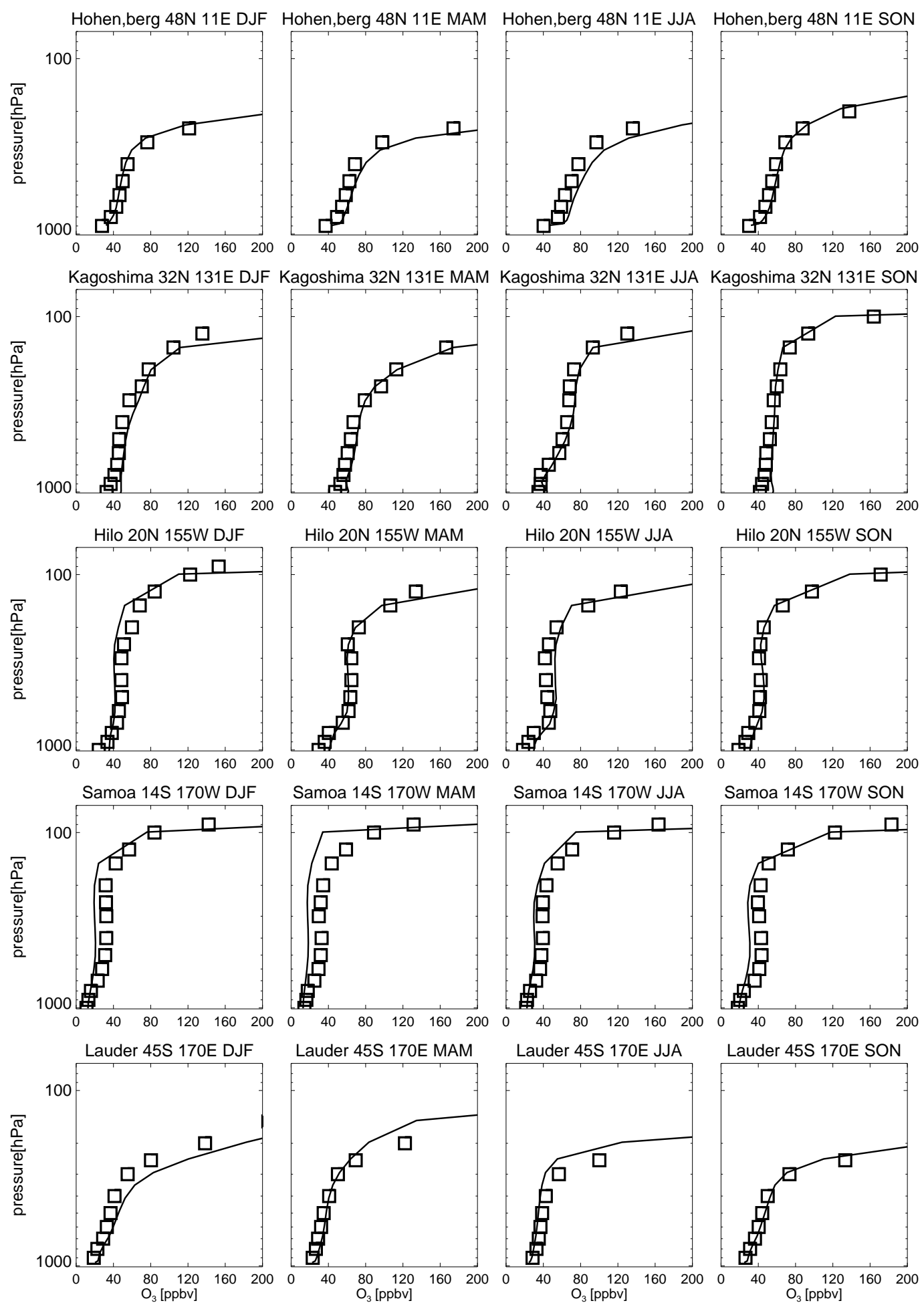

Fig. 3. Seasonal averaged $\mathrm{O}_{3}$ profile (ppbv) by measurements (symbols) and by calculations (lines). Data from Logan (1999).

production, destruction and transport. The ozone budget depends critically on the concentration of ozone precursors and comprises the chemical production and destruction of $\mathrm{O}_{3}$, stratosphere/troposphere exchange (STE) and dry deposition at the surface. Although models can generally reproduce the observations of $\mathrm{O}_{3}$ concentrations, there are large differences 
Table 3. Tropospheric budgets. Units are Tg/yr unless stated differently.

\begin{tabular}{llllll}
\hline & $2000(\mathrm{~A})$ & $2100(\mathrm{~B})$ & $2100(\mathrm{C})$ & $2100(\mathrm{D})$ & $2100(\mathrm{E})$ \\
\hline $\mathrm{NO}+\mathrm{HO}_{2}$ & 2464 & 5095 & 5322 & 5311 & 5556 \\
$\mathrm{NO}+\mathrm{CH}_{3} \mathrm{O}_{2}$ & 811 & 1833 & 2074 & 2014 & 2179 \\
$\mathrm{NO}+\mathrm{RO}_{2}$ & 346 & 625 & 627 & 695 & 643 \\
Total chemical production & 3620 & 7550 & 8022 & 8018 & 8376 \\
\hline $\mathrm{O}^{1} \mathrm{D}+\mathrm{H}_{2} \mathrm{O}$ & 1737 & 3167 & 3794 & 3756 & 3943 \\
$\mathrm{OH}_{3}$ & 343 & 667 & 749 & 707 & 806 \\
$\mathrm{HO}_{2}+\mathrm{O}_{3}$ & 965 & 2239 & 2384 & 2441 & 2477 \\
Isoprene+O & 64 & 57 & 54 & 106 & 52 \\
Total chemical loss & 3108 & 6128 & 6980 & 7029 & 7276 \\
\hline Net chemical production & 512 & 1422 & 1042 & 989 & 1100 \\
$\mathrm{STE}$ & 452 & 430 & 773 & 774 & 772 \\
Dry deposition & 1035 & 1767 & 1695 & 1684 & 1746 \\
$\mathrm{O}_{3}$ burden $(\mathrm{Tg})$ & 314 & 549 & 530 & 527 & 546 \\
OH burden $(\mathrm{Mg})$ & 172 & 201 & 223 & 207 & 234 \\
Global mean CH & 11.3 & 11.2 & 9.4 & 10.0 & 9.0 \\
Lightning $\mathrm{NO}_{\mathbf{x}}$ emission $\left(\mathrm{Tg}\left[\mathrm{O}_{3}\right] / \mathrm{yr}\right)$ & 10.3 & 10.3 & 12.6 & 12.6 & 12.6 \\
\hline
\end{tabular}

in tropospheric $\mathrm{O}_{3}$ budgets between different models (see, e.g., Table 4.12 of IPCC (Houghton et al., 2001) and Table 5 of Shindell et al., 2001): the net chemical production varies from -810 to $550 \mathrm{Tg} / \mathrm{year}$; the flux from the stratosphere to the troposphere from 390 to $1440 \mathrm{Tg} /$ year; and the dry deposition from 533 to $1237 \mathrm{Tg} /$ year. Most recent intermodel comparison shows that differences in $\mathrm{O}_{3}$ budget caculations are reduced among models for the present-day scenario (see Stevenson et al., 2006). In our calculations (see Table 3 - scenario A), the net influx from the stratosphere is $452 \mathrm{Tg} /$ year which is within the range reported by Houghton (2001) and Stevenson et al. (2006). The main chemical reactions contributing to $\mathrm{O}_{3}$ production are reactions between $\mathrm{NO}$ and hydroxyl peroxide/other peroxyl radicals $\left(\mathrm{RO}_{2}\right)$. The chemical destruction channels are mainly through the reactions $\mathrm{H}_{2} \mathrm{O}+\mathrm{O}\left({ }^{1} \mathrm{D}\right)$ and $\mathrm{O}_{3}+\mathrm{HO}_{\mathrm{x}}$. The net chemical production (NCP) of $512 \mathrm{Tg} /$ year calculated from these main terms is within the reported range. Note that it is a small residual of two large production and destruction terms which are 3620 to $3108 \mathrm{Tg} /$ year, respectively, in our calculation. Gross ozone production varies greatly across models on present-day simulations (2300 to $5300 \mathrm{Tg} / \mathrm{year}$ ) (Stevenson et al., 2006) and is likely due to differences in complexities of chemical mechanisms included (see also discussions by Wu et al., 2007). Our dry deposition of $1035 \mathrm{Tg} /$ year is at the high end of the model range. The total tropospheric burden of $314 \mathrm{Tg}$ is within the range seen in other models. We use a 150 ppbv $\mathrm{O}_{3}$ threshold to define tropospheric air. All the budget calculations are the global sum below this threshold.

By adding the isoprene oxidation chemistry, we obtain lower values in both chemical production and destrution of ozone, compared to the ozone budget we calculated previously (see Zeng and Pyle, 2003) without the isoprene scheme. Note, however, that in our previous calculation we included an extra $\mathrm{CO}$ source to represent the production from isoprene degradation that was omitted from the original mechanism. The direct emission of $\mathrm{CO}$ results in more efficient ozone production. Note, also, that we use different emission datasets in these calculations.

\subsection{Nitrogen species}

The model calculated $\mathrm{NO}_{2}$ column averaged for year 2000 is in good agreement with the GOME measurement (not shown). Here we emphasize speciated comparisons; we compare some measured and modelled $\mathrm{NO}_{\mathrm{x}}$ and PAN vertical profiles. The observation data are from short-term aircraft campaigns compiled by Emmons et al. (2000) and should not necessarily compare in detail with model results from a climate simulation. Nevertheless, the modelled $\mathrm{NO}_{\mathrm{x}}$ concentrations are generally in reasonable agreement with observations especially in the mid troposphere (see Fig. 4). The low $\mathrm{NO}_{\mathrm{x}}$ concentrations observed over the remote Pacific regions are well represented by the model. The model does a good job in reproducing higher $\mathrm{NO}_{\mathrm{x}}$ mixing ratios in the lower troposphere during February-March (PEM-West-B) in East Asia, arising from the strong influence of local anthropogenic emissions. Note, in particular, that the " $\mathrm{C}$ " shaped profile found in observation along the Japanese coast is well simulated by the model. Biomass burning in Africa and South America during September-November (TRACE-A) leads to a large near-surface enhancement of $\mathrm{NO}_{\mathrm{x}}$ mixing ratios in the surrounding regions. The $\mathrm{NO}_{\mathrm{x}}$ profile in East Brazil is well reproduced but the model underestimates $\mathrm{NO}_{\mathrm{x}}$ mixing ratios in the lower troposphere in South Africa during the biomass burning season. The higher mixing ratios of $\mathrm{NO}_{\mathrm{x}}$ 

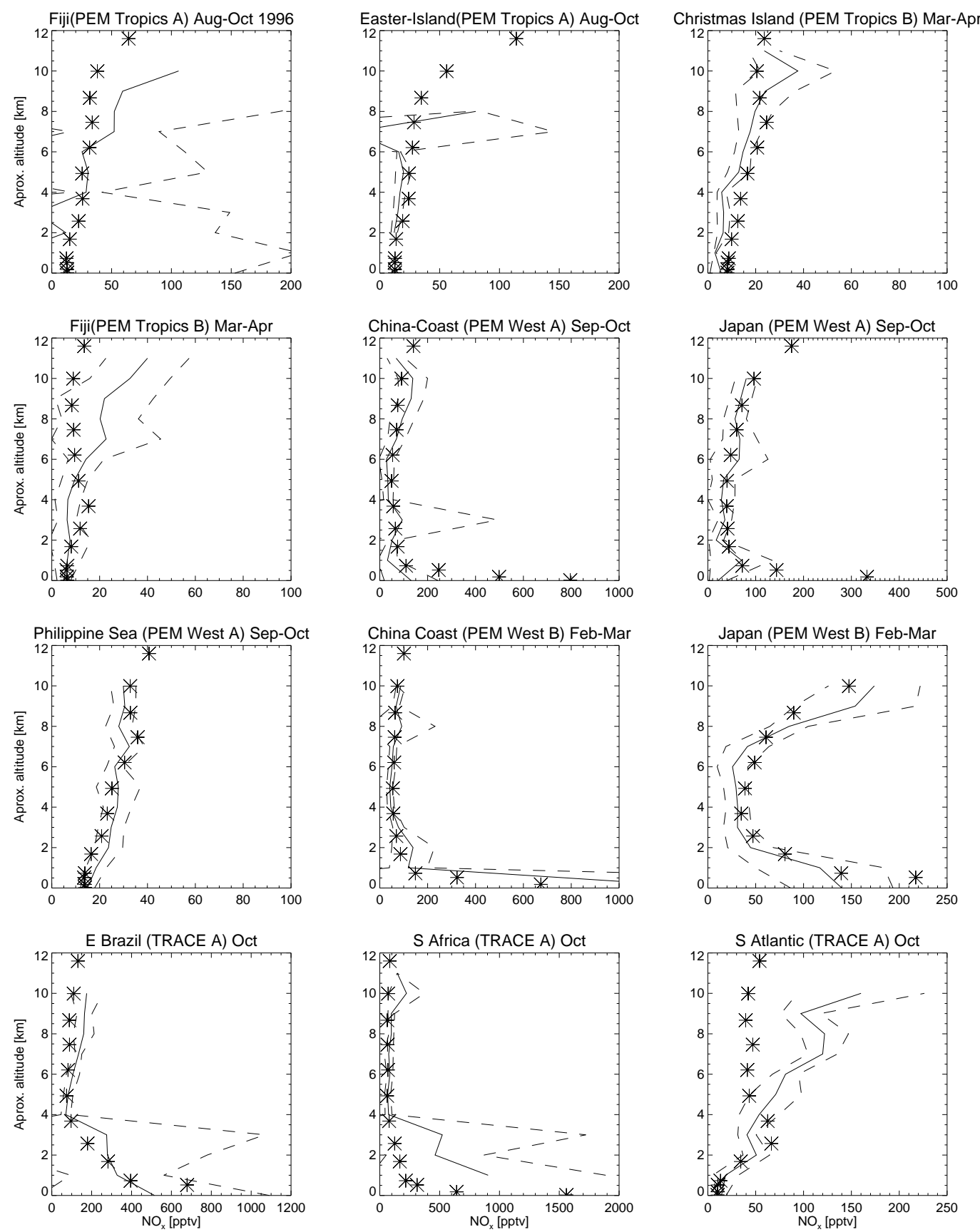

Fig. 4. Observed and simulated profiles of $\mathrm{NO}_{\mathrm{x}}$ (pptv) for various locations and seasons. Solid and dashed lines indicate measured mean values and standard deviations respectively. Model calculations are indicated by symbols. Observation data are taken from Emmons et al. (2000).

seen in the middle to upper tropospheric over the South Atlantic during September-November are from biomass burning emissions that have been transported from the continents (PEM-Tropics-A and Tracer-A) (see Emmons et al., 2000, and references therein); this is not reproduced by the model. Note that the modelled data are the average over 5 years; hence they do not capture interannual variability of emissions (which are the same for every year of the model run) and meterological conditions. Savage (private communication, 2008) has recently pointed to the importance of interannual variations in meteorology for explaining observed $\mathrm{NO}_{\mathrm{x}}$. 

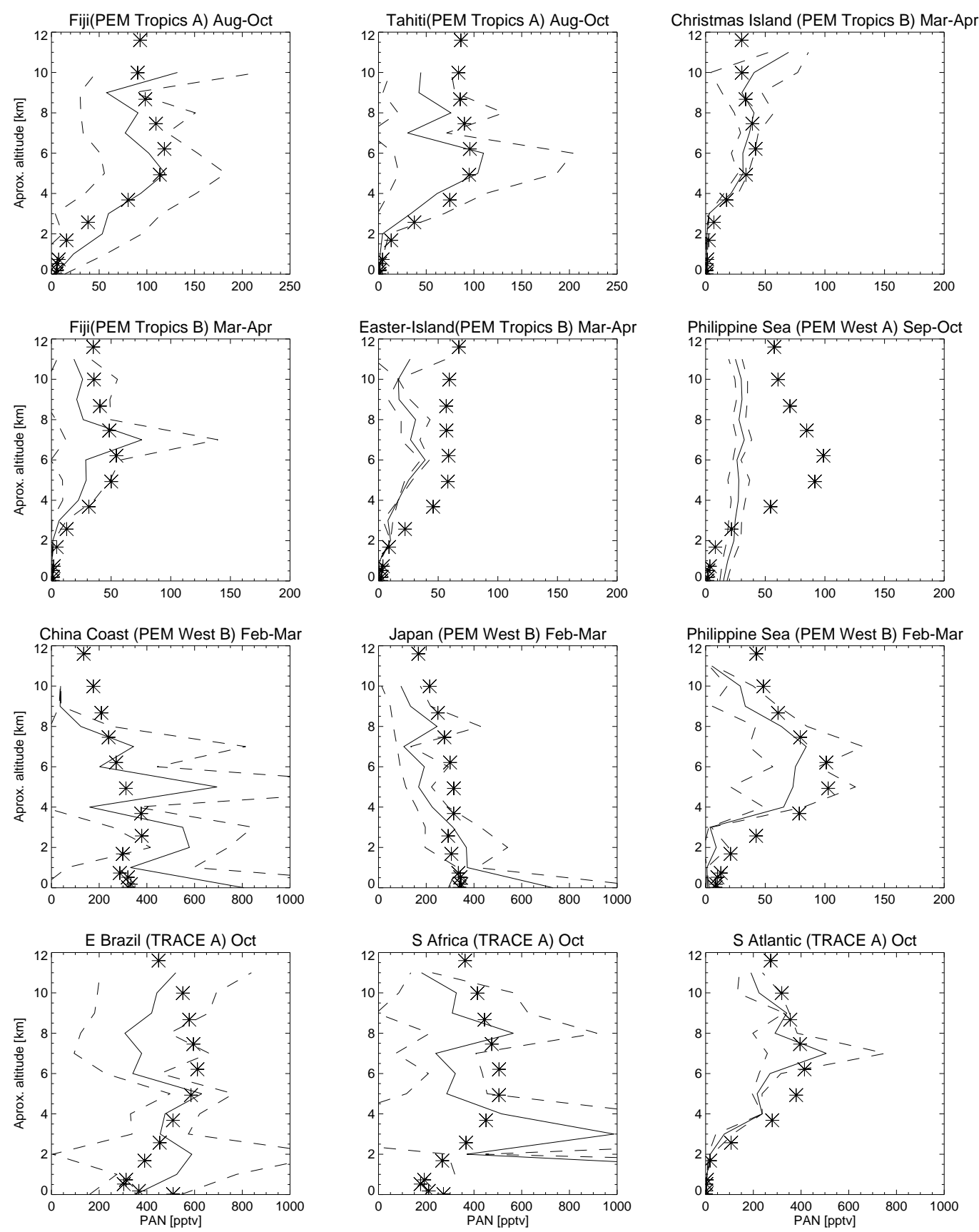

Fig. 5. Observed and simulated PAN (pptv) as indicated in Fig. 4.

A comparison of modelled and observed PAN is shown in Fig. 5. Modelled PAN depends strongly on the magnitude of the VOC and $\mathrm{NO}_{\mathrm{x}}$ emissions sources and the regional meteorology, as well as on the precise hydrocarbon degradation scheme included. With isoprene chemistry in this version of the model, modelled PAN has been improved considerably compared to the previous version without isoprene chemistry which systematically underestimated PAN (not shown). The model simulates well the increase of PAN with altitude over the oceans. The peak observed in the Pacific and Atlantic oceans in the 4-8 km region during PEMTropics-A and Tracer-A, associated with the transport of PAN from South America, Australia and Africa, is reproduced by the model. PAN profiles over the China Coast and Japan observed during PEM West B reflect strong outflow of pollutants from Asia to the North Pacific with high 

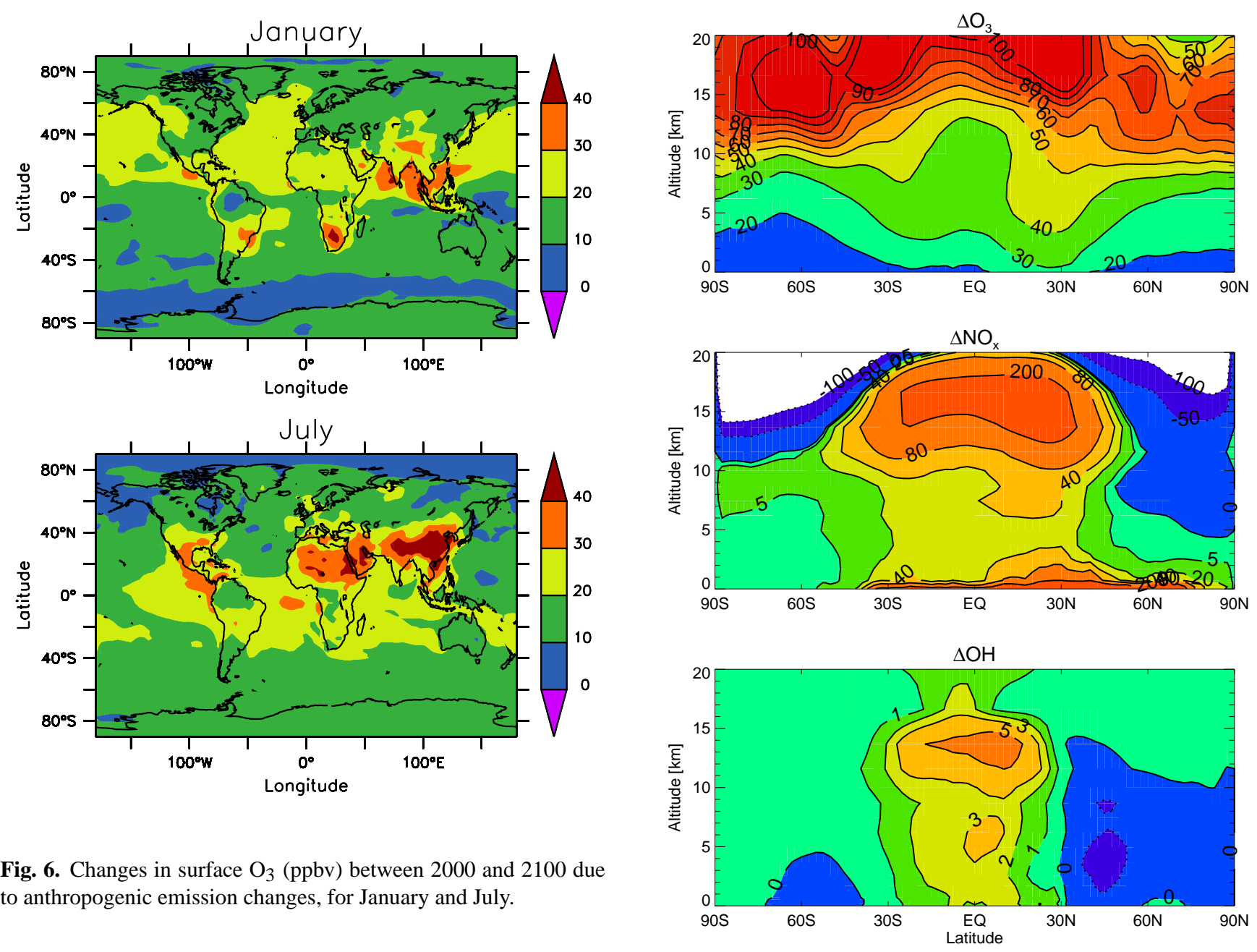

Fig. 6. Changes in surface $\mathrm{O}_{3}$ (ppbv) between 2000 and 2100 due to anthropogenic emission changes, for January and July.

values seen near the surface; the model simulates this feature well. PAN over the Philippine Sea peaks in the middle troposphere reflecting the transport of PAN from the Asian continent (PEM West B). However, the seasonal change of PAN over the Philippine Sea is not well captured by the model. High levels of PAN observed during September-November (TRACE A) are the result of biomass burning in Africa and South America and the transport to the South Atlantic ocean. The model well simulates the vertical profiles of PAN in these regions. Addition of isoprene to the model has led to a much improved $\mathrm{NO}_{\mathrm{y}}$ distribution compared with our earlier model simulations.

\section{Tropospheric composition changes between 2000 and 2100}

\subsection{Response to anthropogenic emission changes}

Figure 6 shows calculated changes in surface $\mathrm{O}_{3}$ for January and July between 2000 and 2100 assuming only changes in emissions (i.e. Run B - Run A). In the Northern Hemisphere, increases of $\mathrm{O}_{3}$ peaking above $40 \mathrm{ppbv}$ are calculated over

Fig. 7. Changes in zonal and annual mean $\mathrm{O}_{3}$ (ppbv), $\mathrm{NO}_{\mathrm{x}}$ (pptv) and $\mathrm{OH}\left(10^{5}\right.$ molecules $\left./ \mathrm{cm}^{3}\right)$ between 2000 and 2100 due to anthropogenic emission changes.

the polluted continents, with the largest increase of $\mathrm{O}_{3}$ in the Far East in summer. The areas of larger ozone increase are regions where rapid economic growth and population increase are predicted. In January, there are significant increases of $\mathrm{O}_{3}$ over the oceans. For the Pacific region this corresponds to an outflow of pollutants from Asia, highlighting the potential importance of the Asian plume and its impact on global $\mathrm{O}_{3}$ levels in the future. In the Southern Hemisphere, $\mathrm{O}_{3}$ increases of $30 \mathrm{ppbv}$ are calculated in South Africa and South America. The long range transport of $\mathrm{O}_{3}$ from these regions is evident: There is a background $\mathrm{O}_{3}$ increase of up to 5$15 \mathrm{ppbv}$ in the southern hemisphere in remote oceanic areas. Increased surface emissions of $\mathrm{O}_{3}$ precursors not only contribute to $\mathrm{O}_{3}$ formation in the source region (air quality) but also increase the $\mathrm{O}_{3}$ level in remote regions through longrange transport. 


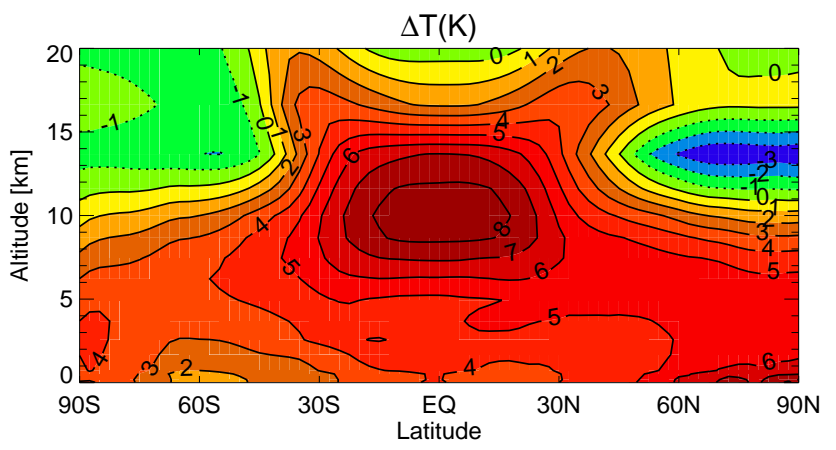

Fig. 8. Changes in zonal and annual mean temperature $(\mathrm{K})$ between 2000 and 2100 (double $\mathrm{CO}_{2}$ ).

Figure 7 shows the calculated zonally averaged $\mathrm{O}_{3}$ changes between 2000 and 2100 (B-A). The largest increase of $\mathrm{O}_{3}$ occurs in the northern hemisphere subtropical free troposphere; it is a consequence of increases in emissions in northern latitudes and weak destruction of $\mathrm{O}_{3}$ above the boundary layer. The $\mathrm{O}_{3}$ increase in the stratosphere results mainly from transport of $\mathrm{O}_{3}$ precursors from the troposphere, although the increase is relatively small compared to the background. Figure 7 also shows $\mathrm{NO}_{\mathrm{x}}$ changes for B-A; largest increases are in the boundary layer, where the direct emissions occur, and in the upper tropical troposphere where its lifetime is long. There, large increases of $\mathrm{NO}_{\mathrm{x}} \mathrm{re}-$ sult in substantial $\mathrm{O}_{3}$ production. The decrease of $\mathrm{NO}_{\mathrm{x}}$ in the stratosphere is a result of decreased $\mathrm{NO}_{\mathrm{x}}$ to $\mathrm{HNO}_{3}$ ratio (not shown).

The global tropospheric $\mathrm{O}_{3}$ budgets for scenario $\mathrm{B}$ are shown in Table 3. The net stratospheric influx is about 5\% smaller than in scenario A. This small net decrease is the result of a larger tropical troposphere-to-stratosphere $\mathrm{O}_{3}$ flux in $\mathrm{B}$ that more than offsets the middle latitude $\mathrm{O}_{3}$ influx from the stratosphere. Chemical production increases substantially as a result of increasing emissions of $\mathrm{O}_{3}$ precursors. Chemical destruction also increases in response to the increased $\mathrm{O}_{3}$. The overall net chemical production of $\mathrm{O}_{3}$ is nearly three times that of scenario A. With higher $\mathrm{O}_{3}$, the dry deposition increases by a factor of 1.7 . The average tropospheric $\mathrm{O}_{3}$ burden increases from 314 to $549 \mathrm{Tg}$.

$\mathrm{OH}$ controls the oxidizing capacity in the troposphere and its distribution depends critically on $\mathrm{NO}_{\mathrm{x}}$ and hydrocarbons. Increases of $\mathrm{NO}_{\mathrm{x}}$ and $\mathrm{O}_{3}$ tend to increase $\mathrm{OH}$ and increases of $\mathrm{CO}$ and $\mathrm{CH}_{4}$ depress $\mathrm{OH}$. Figure 7 shows changes in $\mathrm{OH}$ in response to changes in $\mathrm{NO}_{\mathrm{x}} / \mathrm{VOCs}$ emissions; there are increases throughout the tropical troposphere with the largest increase in the upper troposphere, corresponding to the increase of $\mathrm{NO}_{\mathrm{x}}$ there. $\mathrm{OH}$ decreases in a large area of the $\mathrm{NH}$ and some of the $\mathrm{SH}$ as a result of increases of VOCs over the continents. Although the tropospheric $\mathrm{OH}$ burden increases by $17 \%$ from run $\mathrm{A}$ to run $\mathrm{B}$, the methane lifetime decreases only slightly from 11.3 to 11.2 years (see Table 3 ); the methane lifetime is mainly influenced by the changes in lower tropospheric $\mathrm{OH}$.

\subsection{Response to climate change}

The impact of climate change on the $\mathrm{O}_{3}$ distribution and its budget is assessed by considering the differences between run $\mathrm{C}$ and run $\mathrm{B}$, where only differences arise from the doubling $\mathrm{CO}_{2}$ (see Table 1). Figure 8 shows the differences in temperatures caused by a doubled $\mathrm{CO}_{2}$ forcing. The annual and global mean surface temperature increase is $4 \mathrm{~K}$ (higher at high latitudes) and reaches $9 \mathrm{~K}$ in the upper tropical troposphere. Cooling in the lower stratosphere occurs in the double- $\mathrm{CO}_{2}$ climate. Specific humidity increases throughout the troposphere with substantial increase in the tropical boundary layer by $20 \%$ (not shown).

Figure 9 shows zonal mean changes of $\mathrm{O}_{3}$ due to climate change for January, April, July and October. It shows that for all seasons enhanced chemical destruction, due to increased water vapour in the projected future climate, dominates $\mathrm{O}_{3}$ changes in the tropical troposphere. A pronounced feedback is the substantial increase of $\mathrm{O}_{3}$ (over $200 \mathrm{ppbv}$ ) in the extratropical low stratosphere which is a response to changes in circulation; the enhanced Brewer-Dobson circulation more rapidly lifts $\mathrm{O}_{3}$-poor air upwards in the tropics and transports $\mathrm{O}_{3}$-rich air into high latitudes. This leads to an $\mathrm{O}_{3}$ reduction in the upper tropical troposphere and an $\mathrm{O}_{3}$ buildup at high latitudes in the lower stratosphere, (in part also due to reduced ozone destruction in the cooler lower stratosphere, consistent with our earlier finding based on an older model version, Zeng and Pyle, 2003). In a recent multimodel comparison (Butchart et al., 2006) most participating models also produce an increase in the stratosphere-troposphere mass exchange rate in response to growing greenhouse gas concentrations. Consequently, the enhanced STE transports stratospheric $\mathrm{O}_{3}$ more rapidly to the troposphere leading to significant increases of $\mathrm{O}_{3}$ in the free troposphere; for the $\mathrm{NH}$ this feature is most pronounced in April when STE normally maximizes. The influence of STE peaks in Austral winter/spring for the $\mathrm{SH}$, leading to increased $\mathrm{O}_{3}$ in the free troposphere which also propagates to the lower troposphere. The elevated $\mathrm{O}_{3}$ levels over the southern midlatitudes and the Antarctic in July and October shown in Fig. 9 seem linked to increased stratosphere to troposphere transport of $\mathrm{O}_{3}$ and low surface $\mathrm{O}_{3}$ deposition rates at these locations (water and snow surfaces). Note that the decreases of $\mathrm{O}_{3}$ along the tropopause are due to tropopause lifting in a changed climate.

Responses of ground-level $\mathrm{O}_{3}$ to climate change are highly complex. Figure 10 shows monthly mean surface $\mathrm{O}_{3}$ changes for January, April, July and October, in response to a doubling of $\mathrm{CO}_{2} . \quad \mathrm{O}_{3}$ changes are predominately negative through increased water vapour for all the seasons, with the largest decrease over tropical oceans. However, we note some prominent, seasonally-varying $\mathrm{O}_{3}$ increases, e.g., over 

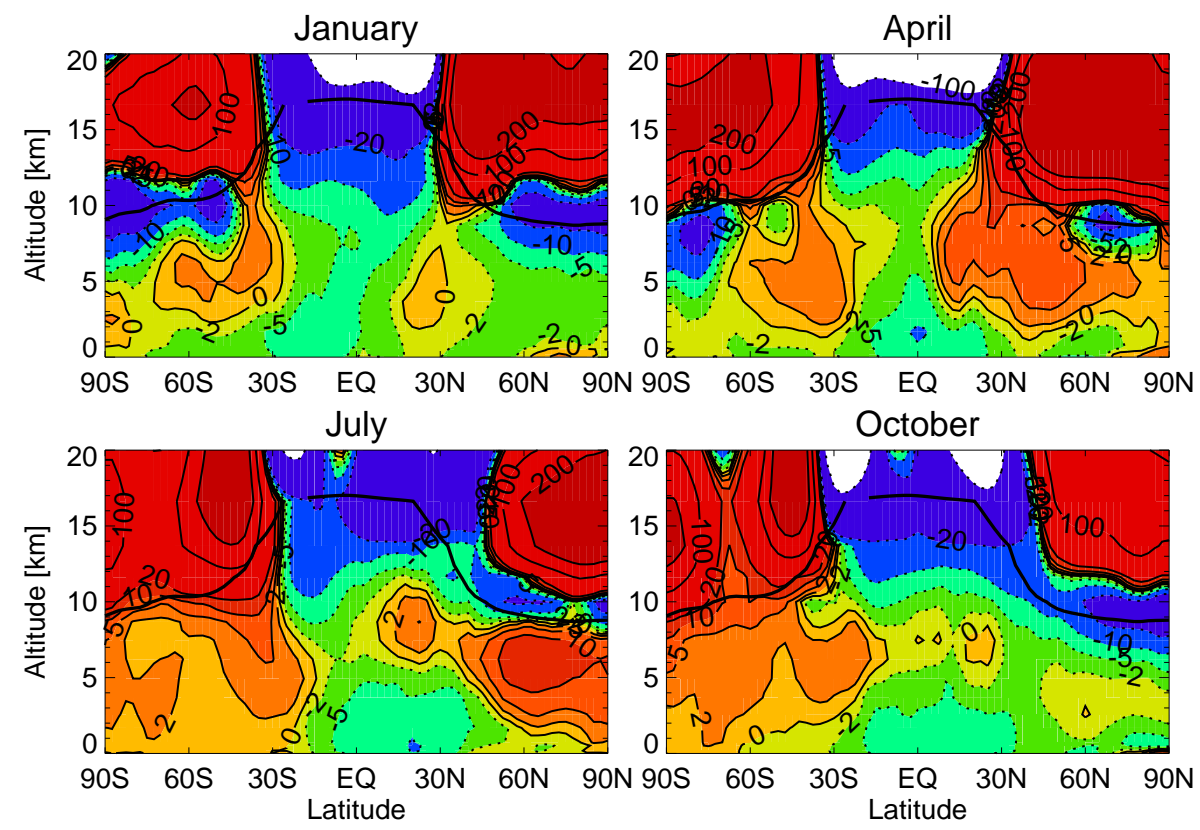

Fig. 9. Changes in zonal mean $\mathrm{O}_{3}$ (ppbv) between 2000 and 2100 due to climate change (C-B), for January, April, July and October.
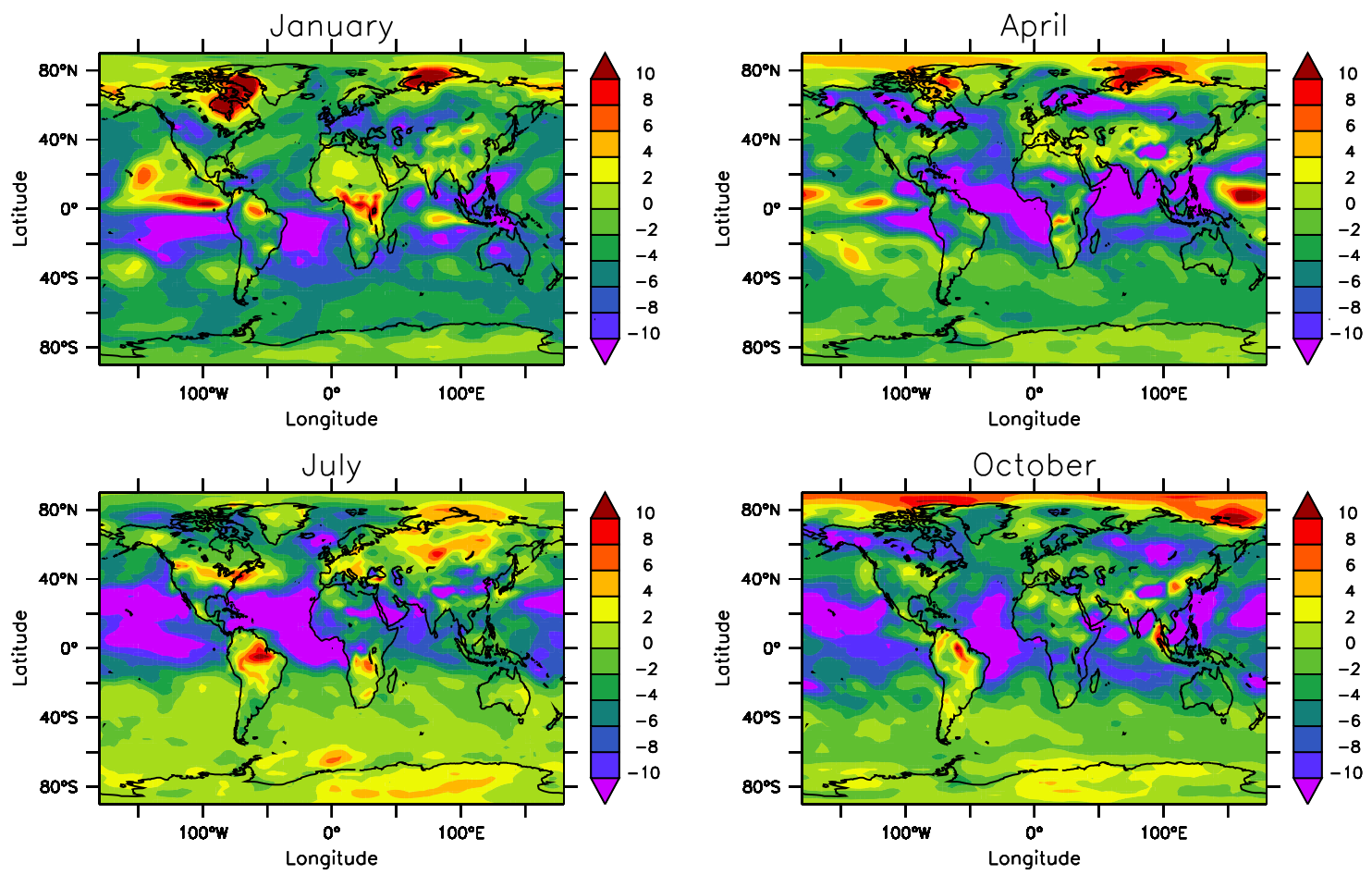

Fig. 10. Changes in surface $\mathrm{O}_{3}$ (ppbv) between 2000 and 2100 due to climate change, for January, April, July and October.

some of the polar regions, over the Southern Ocean in Austral winter, and over some of the continents, with largest increases over Amazonia, Africa, North America, southern and central Europe in summer. The significant increase of $\mathrm{O}_{3}$ over the Arctic in April shown in Fig. 10 (most pronounced in February/March, not shown) may be due to an intensified 

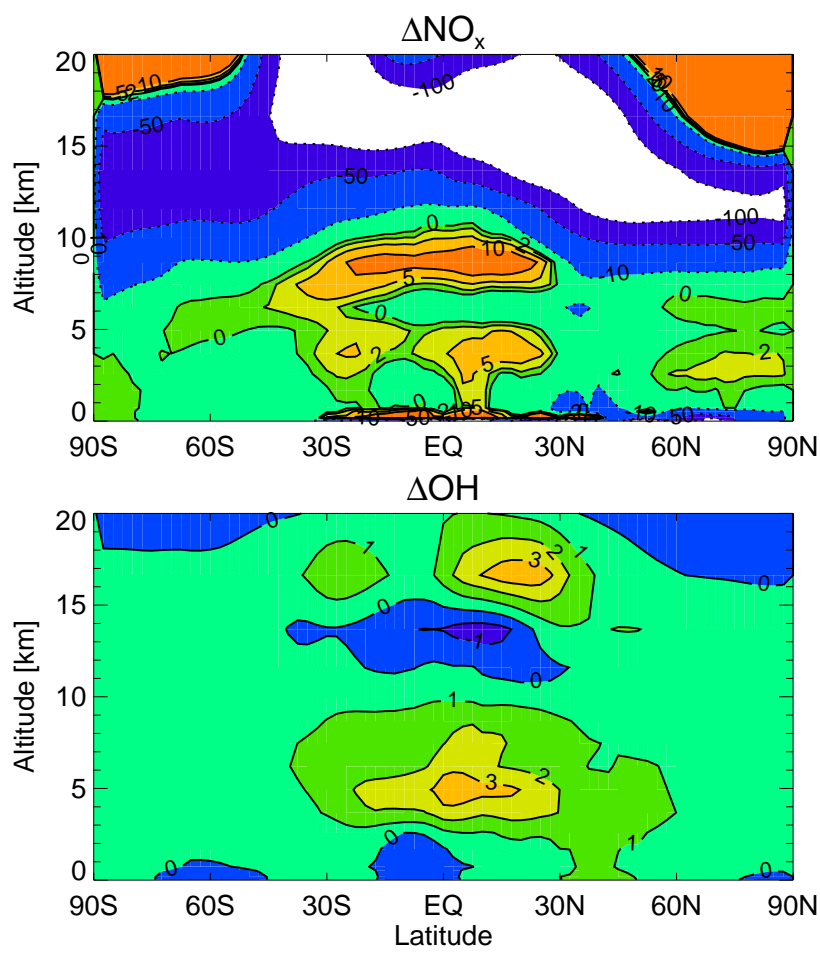

Fig. 11. Changes in annual and zonal mean $\mathrm{NO}_{\mathrm{x}}$ (pptv) and $\mathrm{OH}$ $\left(10^{5}\right.$ molecules $\left./ \mathrm{cm}^{3}\right)$ due to climate change.

poleward transport of $\mathrm{O}_{3} / \mathrm{O}_{3}$-precursors from North America and Europe, possibly associated with increased STE, but needs further investigation. There is also some increase of $\mathrm{O}_{3}$ over the Arctic in October following summer increases of surface $\mathrm{O}_{3}$ over Europe and North America. We also note that, to some extent, increases of surface $\mathrm{O}_{3}$ are linked to increased surface temperatures. A number of mechanisms can lead to increased $\mathrm{O}_{3}$ production following increased temperature: 1) favoured production of $\mathrm{HO}_{\mathrm{x}}$ due to mostly positive temperature-dependencies of $\mathrm{CH}_{4} / \mathrm{VOC}$ oxidation reaction rate constant which fuel ozone formation; our calculations show that increases of $\mathrm{HO}_{\mathrm{x}}$ correlate closely to the increase in $\mathrm{O}_{3}$ (although, especially in this hugely complex system, cause and effect are often difficult to disentangle), and 2) the faster decomposition of PAN which releases $\mathrm{NO}_{2}$ leading to regionally increase of ozone production, especially in the $\mathrm{NH}$ polluted regions. Over Amazonia, southern Africa and southern Europe the model predicts a reduced humidity following the increased temperature which is associated with reduced soil moisture (Cox et al., 2004), reducing the $\mathrm{O}_{3}$ destruction in those regions.

The climate change also comprises changes of convection, which play an important role in redistributing $\mathrm{O}_{3}$ and its precursors in the troposphere (see Lawrence et al., 2003; Doherty et al., 2005). Figure 11 displays $\Delta \mathrm{NO}_{\mathrm{x}}$ for runs $\mathrm{C}-\mathrm{B}$; increases of $\mathrm{NO}_{\mathrm{x}}$ occur mainly in the tropical upper and middle troposphere, which are likely due to increased deep convection and the increased lightning activity respectively. Enhanced convection can transport $\mathrm{NO}_{\mathrm{x}}$ and other $\mathrm{O}_{3}$ precursors to the upper troposphere more efficiently, while intensified lightning produces $\mathrm{NO}_{\mathrm{x}}$ directly in the free troposphere, leading to increased $\mathrm{O}_{3}$ chemical production. On the other hand, increased convection could bring $\mathrm{O}_{3}$-poor air (e.g. from the Pacific "warm pool") to the upper troposphere which contributes to $\mathrm{O}_{3}$ decreases there. The $\mathrm{O}_{3}$ increases at $5-10 \mathrm{~km}$ over the tropics in July and into October shown in Fig. 9 are most likely associated with increased convection/lightning. Note that the large negative changes of $\mathrm{NO}_{\mathrm{x}}$ above $10 \mathrm{~km}$ are partly due to strengthened circulation associated with the double- $\mathrm{CO}_{2}$ climate forcing, and in part due to increased formation of $\mathrm{HNO}_{3}$ from $\mathrm{NO}_{\mathrm{x}}$ in extratropical latitudes, favoured by the lower temperatures.

In a future climate the $\mathrm{OH}$ concentration will be modified following the increase of water vapour, which can subsequently modify the oxidizing capacity of the atmosphere. Responding to a double- $\mathrm{CO}_{2}$ climate, increases of $\mathrm{OH}$ occur throughout the troposphere (Fig. 11) with an important feedback on the methane lifetime. Methane is an important greenhouse gas and is also a key trace gas controlling background $\mathrm{O}_{3}$ concentrations. In these calculations the methane lifetime has shortened considerably (by 1.8 years) in response to the double- $\mathrm{CO}_{2}$ forcing, due not only to increased $\mathrm{OH}$ concentrations but also to the increased reaction rate coefficient of $\mathrm{OH}+\mathrm{CH}_{4}$ which has a strongly positive temperature-dependence.

Impacts of climate change on the chemical and dynamical processes that affect tropospheric $\mathrm{O}_{3}$ are reflected in the $\mathrm{O}_{3}$ budget. Budget calculations (Table 3) show that with climate change included, the tropospheric $\mathrm{O}_{3}$ burden reduces slightly, as a result of several competing processes. The most significant positive feedback is an $80 \%$ increase of net flux of $\mathrm{O}_{3}$ from the stratosphere to the troposphere. Both chemical production and destruction show increases under the climate change. The largest negative chemical change is through reaction $\mathrm{O}\left({ }^{1} \mathrm{D}\right)+\mathrm{H}_{2} \mathrm{O}$ following photolysis of $\mathrm{O}_{3}$. Positive chemical changes are mainly through increased reaction fluxes of $\mathrm{NO}+\mathrm{HO}_{2}$ (by $4.5 \%$ ) and $\mathrm{NO}+\mathrm{CH}_{3} \mathrm{O}_{2}$ (by $13 \%$ ), which lead to $\mathrm{O}_{3}$ production. We note the larger relative increase in $\mathrm{NO}+\mathrm{CH}_{3} \mathrm{O}_{2}$; the driving factor is the strong positive temperature-dependence of the methane oxidation by $\mathrm{OH}$ which favours $\mathrm{CH}_{3} \mathrm{O}_{2}$ production at higher temperatures (Recall that $\mathrm{CH}_{4}$ concentrations are fixed at the same value for runs $\mathrm{B}$ and $\mathrm{C}$ ). Higher $\mathrm{CH}_{4}$ levels could have a significant impact on tropospheric $\mathrm{O}_{3}$ in a future warmer climate. Finally, note that enhanced convection is reflected in a $22 \%$ increase of lightning- $\mathrm{NO}_{\mathrm{x}}$ emission.

We have shown here that climate change has diverse impacts on $\mathrm{O}_{3}$ production, loss and transport, and that the oxidizing capacity of the troposphere is modified by climate change. The feedbacks of climate change on tropospheric ozone are complex. In particular, changes of surface $\mathrm{O}_{3}$ 
(a)

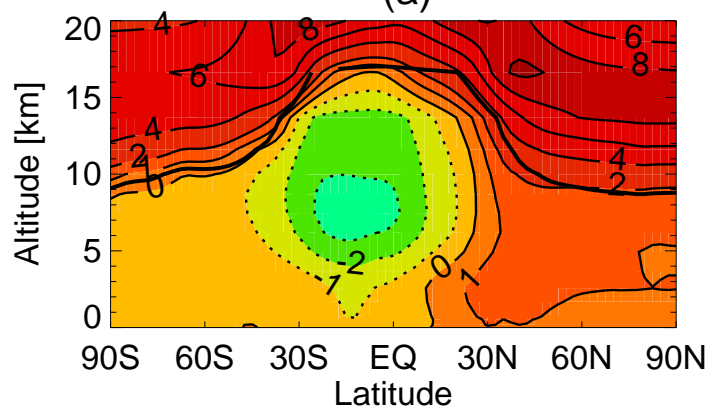

(b)

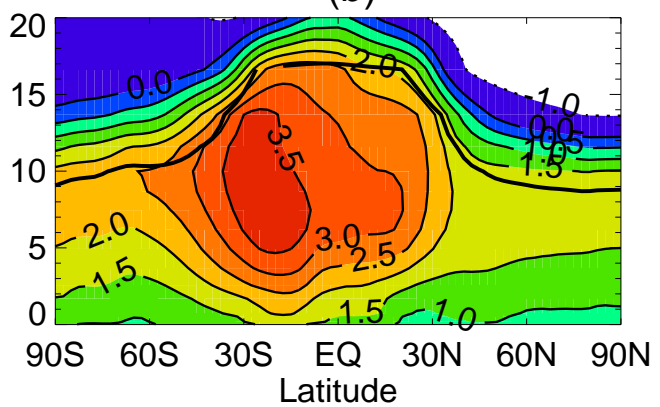

Fig. 12. Changes in annual and zonal mean $\mathrm{O}_{3}$ (ppbv) due to (a) increase of isoprene emissions (D-C) and (b) increase of soil- $\mathrm{NO}_{\mathrm{x}}$ emissions (E-C).

in response to climate change vary regionally and seasonally. More studies are needed to address in detail, for example, how changes in transport patterns can affect surface $\mathrm{O}_{3}$ changes.

5.3 Response to climate change induced natural emission changes

\subsubsection{Increased isoprene emissions}

Relative to scenario $\mathrm{C}$, we increase isoprene emissions by $50 \%$ globally to assess the possible impact on $\mathrm{O}_{3}$. Note that the major emission regions are in the tropics in the maritime continent, in South America and Africa. The Southeast USA is a regionally important extra tropical source. Our calculation shows that increasing isoprene emissions has little impact on the global tropospheric ozone burden, which decreases by less than $1 \%$ (see Table 3 ). However, the spatial distribution of ozone is modified; Fig. 12a shows that ozone generally increases in the northern hemisphere throughout the model domain and decreases in the equatorial and southern subtropical regions. The largest negative change of $\mathrm{O}_{3}$ occurs between $5-10 \mathrm{~km}$ in the southern tropics where $\mathrm{NO}_{\mathrm{x}}$ concentrations are low. Budget calculations (see Table 3) show that with extra isoprene emissions, the gross chemical production is reduced slightly due to a reduced $\mathrm{NO}_{\mathrm{x}}$ level which is consumed by elevated $\mathrm{RO}_{2}$ radicals from isoprene oxidation to form PAN; Fig. 13 shows that PAN increases substantially following the increase of isoprene emissions. $\mathrm{O}_{3}$ loss increases due to increased destruction by reactions with $\mathrm{HO}_{2}$ and isoprene, respectively. Following the reduced $\mathrm{OH}$ level, the global methane lifetime increases by 0.6 years.

The largest impact of the increased isoprene emissions on ozone occurs in summer. Figure $14 \mathrm{a}$ shows $\mathrm{O}_{3}$ changes at the surface for July; $\mathrm{O}_{3}$ generally decreases over the isoprene source regions where $\mathrm{NO}_{\mathrm{x}}$ levels are also low, as a result of ozone destruction (less $\mathrm{O}_{3}$ production) in the $\mathrm{NO}_{\mathrm{x}}$ limited regime. In high $\mathrm{NO}_{\mathrm{x}}$ regions (Europe and Asia), $\mathrm{O}_{3}$

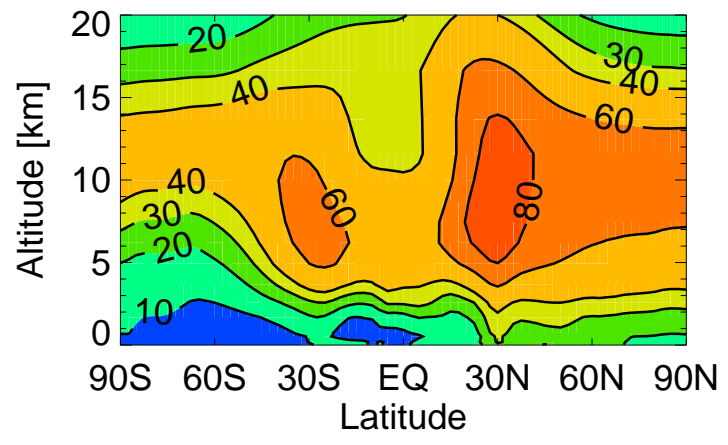

Fig. 13. Changes in annual and zonal mean PAN (pptv) due to increase of isoprene emissions (D-C).

increases by up to 4-6 ppbv due to increased peroxy radicals from the degradation of isoprene which contribute positively to ozone production in the $\mathrm{NO}_{\mathrm{x}}$-rich (VOC-limited) environment. We also find elevated ozone concentrations away from the main emitting sources (e.g. over the North Atlantic and western Africa). This suggests that PAN plays an important role in ozone formation; PAN can transport $\mathrm{NO}_{\mathrm{x}}$ away from its source and contribute to ozone production in remote regions. In our simulation background $\mathrm{O}_{3}$ concentrations have increased by around 1 ppbv except over the southern oceans. We will consider a range of future isoprene scenarios in more detail (Young et al., 2008 ${ }^{1}$; Young, 2007).

Of course, the link between climate and isoprene emission is more complicated than the simple scaling up of the emissions in this sensitivity experiment. Besides the effect of temperature, the magnitude and spatial distribution of isoprene emission is highly dependent on the plant species. Thus, any future natural or anthropogenic land use change, such as the drying of the Amazon rain forest (Cox et al., 2004) or increase in crop growth, would have a large impact on the isoprene emission field. Furthermore, increases in atmospheric $\mathrm{CO}_{2}$ may well decrease isoprene emission 

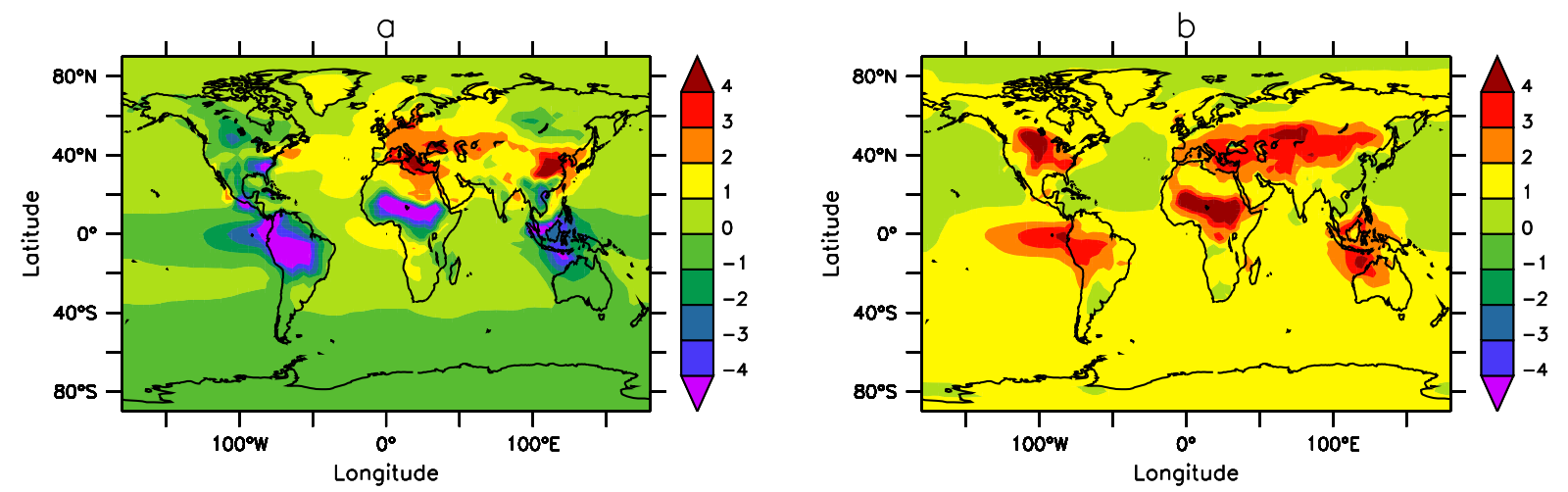

Fig. 14. Changes in surface $\mathrm{O}_{3}$ (ppbv) due to (a) increase of isoprene emissions (D-C) and (b) increase of soil-NO $\mathrm{N}_{\mathrm{x}}$ emissions (E-C). Both changes are for July.

(Rosensteil et al., 2003; Arneth et al., 2007). Other climaterelated factors such as water availability, changes in the flux of photosynthetically active radiation (PAR), nutrient delivery and air pollution, will also effect isoprene and other biogenic emissions, either directly or through their impact on primary productivity.

\subsubsection{Increased soil- $\mathrm{NO}_{\mathrm{x}}$ emissions}

We double the soil- $\mathrm{NO}_{\mathrm{x}}$ emission globally in this experiment and compare run $\mathrm{E}$ to run $\mathrm{C}$ to assess the impact associated with increasing soil- $\mathrm{NO}_{\mathrm{x}}$ emissions. The major emissions regions are the tropics and subtropics with the strongest sources from agriculture, grassland, and tropical rain forests. Results show that increased soil $\mathrm{NO}_{\mathrm{x}}$ has a substantial positive feedback on tropospheric ozone (3\% increase of the tropospheric burden, see Table 3). Both gross chemical production and net chemical production increase compared to run $\mathrm{C}$, which is driven by increased $\mathrm{NO}_{\mathrm{x}}$ levels. Figure $12 \mathrm{~b}$ shows that changes in zonal mean $\mathrm{O}_{3}$ are positive globally with a peak in the southern subtropics, although there is a slight decrease in stratospheric ozone which is related to the ozone destruction by $\mathrm{NO}_{\mathrm{x}}$ in that region. Figure $14 \mathrm{~b}$ shows that increases of $\mathrm{O}_{3}$ at the surface are largely in the $\mathrm{NO}_{\mathrm{x}}$ emitting regions as the result of in-situ chemical production following increased soil- $\mathrm{NO}_{\mathrm{x}}$ emissions. It also shows some large increases of ozone away from the source regions, as a result of the long-range transport. Note also the similarities in the patterns in Fig. 14a and b.

These calculations of the effects of natural emissions on $\mathrm{O}_{3}$ are very simple and the results are merely indicative of possible impacts. However the impacts are potentially significant, and more detailed studies are needed to project future changes of natural emissions which can be included in models.

\section{Conclusions}

We have evaluated an updated tropospheric chemistry model which is incorporated into a version of the UK Met Office climate model. The model is satisfactory in modelling presentday observed tropospheric ozone and nitrogen species. The ozone budget falls within reported ranges. We calculate a net stratospheric to tropospheric ozone flux of $452 \mathrm{Tg} / \mathrm{year}$, a gross $\mathrm{O}_{3}$ chemical production of $3620 \mathrm{Tg}\left(\mathrm{O}_{3}\right) /$ year, and a gross $\mathrm{O}_{3}$ chemical destruction of $3108 \mathrm{Tg} /$ year. However, the gross chemical production of $\mathrm{O}_{3}$ is relatively low compared to a recent multimodel study.

Calculations for a series of 2100 scenarios suggest that projected significant increase of anthropogenic emissions of ozone precursors could contribute to large ozone increases throughout the troposphere. A pessimistic (large emissions) scenario (SRES A2) leads to an unacceptable increase of surface ozone such that there would be significant exceedences of suggested health-related thresholds. An assessment of the impact of climate change on global tropospheric ozone reveals a number of important feedbacks. Increased water vapour leads to increased $\mathrm{O}_{3}$ destruction in the tropics, whereas enhanced stratosphere-troposphere exchange increases the net $\mathrm{O}_{3}$ flux to the troposphere. The $\mathrm{O}_{3}$ changes at the surface in a future climate are complex and regionally varying, and are strongly influenced by changes in temperature, humidity, STE, and hemispheric transport patterns. We draw attention to some particular changes: we find elevated $\mathrm{O}_{3}$ over polluted continents especially during summer months; increase of background $\mathrm{O}_{3}$ over the Southern Ocean and the Antarctic during austral winter/spring; and intensified poleward transport of pollutants from Europe and North America leading to elevated $\mathrm{O}_{3}$ in the Arctic, in particular during winter/spring. Recent studies of the response of tropospheric $\mathrm{O}_{3}$ to climate change reveal diverse model responses (Shindell et al., 2006; Brasseur et al., 2006). Multi-model studies are important to achieve a consensus on 
the impact of future climate change on tropospheric $\mathrm{O}_{3}$, in particular at ground-level.

Changes in convection in a double $\mathrm{CO}_{2}$ climate can modify the $\mathrm{NO}_{\mathrm{x}}$ distribution; enhanced convection lifts $\mathrm{NO}_{\mathrm{x}}$ and other ozone precursors more efficiently in the tropical region which contribute positively to the $\mathrm{O}_{3}$ chemical production through elevated $\mathrm{NO}_{\mathrm{x}}$ and $\mathrm{HO}_{\mathrm{x}}$ in that region. The associated change in lightning-produced $\mathrm{NO}_{\mathrm{x}}$ is approximately a $22 \%$ increase in our calculation and contributes positively to tropospheric ozone formation. However, the effect of the convection on ozone budgets is still uncertain (Doherty et al., 2005) and further studies are needed to quantify to what extent the tropospheric ozone budget is influenced.

Climate change modifies the tropospheric oxidizing capacity considerably. The methane lifetime is shortened by 1.8 years when climate change is included in the calculation, due to increased $\mathrm{OH}$ concentrations in a more humid climate. In contrast, the methane lifetime was not changed significantly in run B which considered just the increases of anthropogenic emissions. In a warmer and wetter climate, methane can play a significant role in ozone formation due to the strong positive temperature dependence of its oxidation rate coefficient. Further studies are needed to assess the role of methane on ozone formation, particularly in a changed climate.

In addition to considering changing anthropogenic emissions in the 2100 climate change experiment, we have also examined idealised changes of some natural emissions and their impact on tropospheric ozone. With a $50 \%$ increase of the isoprene emission, changes in surface ozone range from $-8 \mathrm{ppbv}$ to $6 \mathrm{ppbv}$. The impacts are regionally varying and have a relatively strong seasonal cycle. The largest decreases of surface ozone occur over isoprene source regions (Amazonia, US, Africa and South East Asia) and the largest increases are over China and Europe in summer where $\mathrm{NO}_{\mathrm{x}}$ levels are high. Generally the response to changed isoprene depends on whether the chemical regime is $\mathrm{NO}_{\mathrm{x}}$ - or VOC-limited: so we predict zonal mean ozone decrease in the southern hemisphere and tropics, with ozone increases in the north hemisphere. The increased isoprene emission increases methane lifetime by 0.6 years, which is large compared with changing anthropogenic emissions. By doubling soil- $\mathrm{NO}_{\mathrm{x}}$ emissions, we obtain substantial increases of ozone over emitting regions and a 0.4 years reduction on methane lifetime. Changes in biogenic emissions, which are mainly from tropics and subtropics, can significantly affect the oxidizing capacity of the troposphere. More study is needed to reduce the uncertainty in present estimates of natural emissions. Accurate projections of the future biogenic emissions are crucial to assessing chemistry-climate-biosphere feedbacks.
Acknowledgements. This work is funded by the NERC National Centre for Atmospheric Science (NCAS). The anthropogenic emission data are made available by the ACCENT community. Hadley Centre is thanked for the use of the UM. PJY is funded by NERC through a studentship with a CASE award from the UKMO.

Edited by: R. Vautard

\section{References}

Arneth, A., Niinemets, U., Pressley, S., et al.: Process-based estimates of terrestrial ecosystem isoprene emissions, Atmos. Chem. Phys., 7, 31-53, 2007,

http://www.atmos-chem-phys.net/7/31/2007/.

Atkinson, R., Baulch, D. L., Cox, R. A., Hampson, R. F., Kerr, J. A., Rossi, M. J., and Troe, J.: Evaluated kinetic and photochemical data for atmospheric chemistry, organic species: Supplement VII, J. Phys. Chem., 28(2), 191-393, 1999.

Barrie, L. A., Bottenheim, J. W., Schell, R. C., Crutzen, P. J., and Rasmussen, R. A.: Ozone destruction and photochemical reactions at polar sunrise in the lower Arctic atmosphere, Nature, 334, 138-140, 1988.

Berntsen, T. K., Myhre, G., Stordal, F., and Isaksen, I. S. A.: Time evolution of tropospheric ozone and its radiative forcing, J. Geophys. Res., 105, 8915-8930, 2000.

Brasseur, G., Kiehl, J. T., Müller, J.-F., Schneider, T., Granier, C., Tie, X., and Hauglustaine, D.: Past and future changes in global tropospheric ozone: Impact on radiative forcing, Geophys. Res. Lett., 25, 3807-3810, 1998.

Brasseur, G. P., Schultz, M., Granier, C., Saunois, M., Diehl, T., Botzet, M., Roeckner, E., Walters, S.: Impact of climate change on the future chemical composition of the global troposphere, J. Climate, 19, 3932-3951, 2006.

Butchart, N., Scaife, A. A., Bourqui, M., et al.: Simulations of anthropogenic change in the strength of the Brewer-Dobson circulation, Clim. Dynam., 27, 727-741, 2006.

Carver, G. D. and Stott, P. A.: IMPACT: An implicit time integration scheme for chemical species and families, Ann. Geophys., 18, 337-346, 2000, http://www.ann-geophys.net/18/337/2000/.

Collins, W. J., Derwent, R. G., Garnier, B., Johnson, C. E., Sanderson, M. G., and Stevenson, D. S.: The effect of stratospheretroposphere exchange on the future tropospheric ozone trend, J. Geophys. Res., 108, 8528, doi:10.1029/2002JD002617, 2003.

Cox, P. M., Betts, R. A., Collins, M., Harris, P. P., Huntingford, C, and Jones, C. D.: Amazonian forest dieback under climatecarbon cycle projections for the 21 st Century, Theor. Appl. Climatol., 78, 137-156, 2004.

Cullen, M. J. P.: The unified forecast/climate model, Meteorol. Mag., 122, 81-94, 1993.

DeMore, W. B., Sander, S. P., Golden, D. M., Hampson, R. F., Kurylo, M. J., Howard, C. J., Ravishankara, A. R., Kolb, C. E., and Molina, M. J.: Chemical Kinetics and Photochemical Data for Use in Stratospheric Modeling, evaluation number 12: Report Number: JPL-Publ-97-4, Jet Propulsion Laboratory, Pasadena, CA, 1997.

Dentener, F., Stevenson, D., Cofala, J., Mechier, R., Amann, M., Bergamaschi, P., Raes, F., and Derwent, R.: The impact of air 
pollutant and methane emission controls on tropospheric ozone and radiative forcing: CTM calculations for the period 19902030, Atmos. Chem. Phys., 5, 1731-1755, 2005, http://www.atmos-chem-phys.net/5/1731/2005/.

Doherty, R. M., Stevenson, D. S., Collins, W. J., and Sanderson, M. G.: Influence of convective transport on tropospheric ozone and its precursors in a chemistry-climate model, Atmos. Chem. Phys., 5, 3205-3218, 2005, http://www.atmos-chem-phys.net/5/3205/2005/.

Edwards, J. M. and Slingo, A.: Studies with a flexible new radiation code. I: Choosing a configuration for a large-scale model, Q. J. Roy. Meteor. Soc., 122, 689-719, 1996.

Emmons, L. K., Hauglustaine, D. A., Müller, J.-F., Carroll, M. A., Brasseur, G. P., Brunner, D., Staehelin, J., Thouret, V., and Marenco, A.: Data composites of airborne observations of tropospheric ozone and its precursors, J. Geophys. Res., 105(D16), 20 497-20 538, 2000.

Forster, P. M. F., Johnson, C. E., Law, K. S., Pyle, J. A., and Shine, K. P.: Further estimates of radiative forcing due to tropospheric ozone, Geophys. Res. Lett., 23, 3321-3324, 1996.

Giannakopoulos, C., Chipperfield, M. P., Law, K. S., and Pyle, J. A.: Validation and intercomparison of wet and dry deposition schemes using ${ }^{210} \mathrm{~Pb}$ in a global three-dimensional off-line chemical transport model, J. Geophys. Res., 104, 23 761-23 784, 1999.

Gregory, D. and Rowntree, P. R.: A mass flux convection scheme with representation of cloud ensemble characteristics and stability dependent closure, Mon. Weather Rev., 118, 1483-1506, 1990.

Grenfell, J. L., Shindell, D. T., Koch, D., and Rind, D.: Chemistryclimate interactions in the Goddard Institute for Space Studies general circulation model 2, New insights into modeling the preindustrial atmosphere, J. Geophys. Res., 106, 33 435-33 451, 2001.

Guenther, A., Hewitt, C. N., Erickson, D., et al.: A global model of natural volatile organic-compound emissions, J. Geophys. Res., 100, 8873-8892, 1995.

Hauglustaine, D. A., Granier, C., Brasseur, G. P. and Mégie, G.: The importance of atmospheric chemistry in the calculation of radiative forcing on the climate system, J. Geophys. Res., 99, 1173-1186, 1994.

Hauglustaine, D. A. and Brasseur, G. P.: Evolution of tropospheric ozone under anthropogenic activities and associated radiative forcing of climate, J. Geophys. Res., 106, 32 337-32 360, 2001.

Hauglustaine, D. A., Lathiere, J., Szopa, S., and Folberth, G. A.: Future tropospheric ozone simulated with a climatechemistry-biosphere model, Geophys. Res. Lett., 32, L24807, doi:10.1029/2005GL024031, 2005.

Houghton, J. T., Ding, Y., Griggs, D. J., Noguer, M., van der Linden, P. J., Dai, X., Maskell, K., and Johnson, C. A.: Climate Change 2001: The Scientific Basis, Cambridge Univ. Press, Cambridge, UK, 2001.

Johns, T. C., Gregory, J. M., Ingram, W., J., et al.: Anthropogenic climate change for 1860 to 2100 simulated with the HadCM3 model under updated emissions scenarios, Clim. Dynam., 20, 583-612, 2003.

Johnson, C. E., Collins, W. J., Stevenson, D. S., and Derwent, R. G.: Relative roles of climate and emissions changes on future tropospheric oxidant concentrations, J. Geophys. Res., 104, 18631
$18645,1999$.

Langner, J., Bergstrom, R., and Foltescu, V.: Impact of climate change on surface ozone and deposition of sulphur and nitrogen in Europe, Atmos. Environ., 39, 1129-1141, 2005.

Lathiere, J., Hauglustaine, D. A., De Noblet-Ducoudre, N., Krinner, G., and Folberth, G. A.: Past and future changes in biogenic volatile organic compound emissions simulated with a global dynamic vegetation model, Geophys. Res. Lett., 32, L20818, doi:10.1029/2005GL024164, 2005.

Law, K. S. and Pyle, J. A.: Modeling trace gas budgets in the troposphere, 1. Ozone and odd nitrogen, J. Geophys. Res., 98, 18377 18 400, 1993.

Law, K. S., Plantevin, P. H., Shallcross, D. E., Rogers, H. L., Pyle, J. A., Grouhel, C., Thouret, V., and Marenco, A.: Evaluation of modeled $\mathrm{O}_{3}$ using Measurement of Ozone by Airbus In-Service Aircraft (MOZAIC) data, J. Geophys, Res., 103, 25 721-25 737, 1998.

Lawrence, M. G., von Kuhlmann, R., Salzmann, M., and Rasch, P. J.: The balance of effects of deep convective mixing on tropospheric ozone, Geophys. Res. Lett., 30(18), 1940, doi:10.1029/2003GL017644, 2003.

Leonard, B. P., Lock, A. P., and MacVean, M. K.: The NIRVANX scheme applied to one-dimensional advection, Int. J. Numer. Methods for Heat and Fluid Flow, 5, 341-377, 1995.

Li, D. and Shine, K. P.: A 4-D ozone climatology for UGAMP models, UGAMP internal report, 1995.

Logan, J. A.: An analysis of ozonesonde data for the troposphere: Recommendations for testing 3-D models and development of a grided climatology for tropospheric ozone, J. Geophys. Res., 104, 16 115-16 149, 1999.

Marenco, A., Gouget, H., Nédélec, P., Pagés, J.-P., and Karcher, F.: Evidence of a long-term increase in tropospheric ozone from Pic du Midi data series: Consequences: Positive radiative forcing, J. Geophys. Res., 99, 16617-16632, 1994.

Mickley, L. J., Murti, P. P., Jacob, D. J., Logan, J. A., Koch, D. M., and Rind, D.: Radiative forcing from tropospheric ozone calculated with a unified chemistry-climate model, J. Geophys. Res., 104, 30 153-30 172, 1999.

Monson, R. K. and Fall R.: Isoprene emission from aspen leaves: Influence of the environment and relation to photosynthesis and phptorespiration, Plant Physiol., 90, 267-274, 1989.

Murazaki, K. and Hess, P.: How does climate change contribute to surface ozone change over the United States?, J. Geophys. Res., 111, D05301, doi:10.1029/2005JD005873, 2006.

Nakićenović, N., Alcamo, J., Davis, G., et al.: Special Report on Emission Scenarios, Cambridge Univ. Press, Cambridge, UK, 599, 2000.

Olivier, J. G. J. and Berdowski, J. J. M.: Global emissions sources and sinks, in: The Climate System, edited by: Berdowski, J., Guicherit, R., and Heij, B. J., 33-78, A.A. Balkema Publishers/Swets and Zeitlinger Publishers, Lisse, The Netherlands, ISBN-90-5809-255-0, 2001.

Pegoraro, E., Rey, A., Barron-Gafford, G., Monson, R., Malhi, Y., and Murthy, R.: The interacting effects of elevated atmospheric $\mathrm{CO}_{2}$ concentration, drought and leaf-to-air vapour pressure deficit on ecosystem isoprene fluxes, Oecologia, 146, 120 129, 2005.

Pöschl, U., von Kuhlmann, R., Poisson, N., and Crutzen, P. J.: Development and intercomparison of condensed isoprene oxidation 
mechanisms for global atmospheric modeling, J. Atmos. Chem., 37(1), 29-52, 2000.

Price, C. and Rind, D.: A simple lightning parameterization for calculating global lightning distributions, J. Geophys. Res., 97, 9919-9933, 1992.

Price, C. and Rind, D.: Modelling global lightning distributions in a general circulation model, Mon. Weather Rev., 122, 1930-1939, 1994.

Roe, P. L.: Some contributions to the modelling of discontinuous flow, in: Lectures in applied mathematics, "Large-Scale computations in fluid mechanics", (AMS-SIAM summer seminar, La Jolla, CA, USA, 1983), edited by: Engquist, B., Osher, S., and Somerville, R., Am. Math. Soc., 22, part 2, 163 pp., 1985.

Roelofs, G. J., Lelieveld, J., and van Dorland, R: A threedimensional chemistry/general circulation model simulation of anthropogenically derived ozone in the troposphere and its radiative climate forcing, J. Geophys. Res., 102, 23 389-23 401, 1997.

Rosenstiel, T. N., Potosnak, M. J., Griffin, K. L., Fall, R., and Monson, R. K.: Increased $\mathrm{CO}_{2}$ uncouples growth from isoprene emission in an agriforest ecosystem, Nature, 421, 256-259, 2003.

Sanderson, M. G., Jones, C. D., Collins, W. J., Johnson, C. E., and Derwent, R. G.: Effect of climate change on isoprene emissions and surface ozone levels, Geophys. Res. Lett., 30, 1936, doi:10.1029/2003GL017642, 2003.

Senior, C. A. and Mitchell, J. F. B: The time-dependence of climate sensitivity, Geophys. Res. Lett., 27, 2685-2688, 2000.

Sharkey, T. D., Singsaas, E. L., Vanferveer, P. J., and Geron, C.: Field measurements of isoprene emission from trees in response to temperature and light, Tree Physiol., 16, 649-654, 1996.

Shindell, D. T., Grenfell, J. L., Rind, D., Price, C., and Grewe, V.: Chemistry-climate interactions in the Goddard Institute for Space Studies general circulation model 1. Tropospheric chemistry model description and evaluation, J. Geophys. Res., 106, 8047-8076, 2001.

Shindell, D. T., Faluvegi, G., Unger, N., Aguilar, E., Schmidt, G. A., Koch, D. M., Bauer, S. E., and Miller, R. L.: Simulations of preindustrial, present-day, and 2100 conditions in the NASA GISS composition and climate model G-PUCCINI, Atmos. Chem. Phys., 6, 4427-4459, 2006,

http://www.atmos-chem-phys.net/6/4427/2006/.

Sorteberg, A. and Hov, O.: Two parametrizations of the dry deposition exchange for $\mathrm{SO}_{2}$ and $\mathrm{NH}_{3}$ in a numerical model, Atmos. Environ., 30, 1823-1840, 1996.

Stevenson, D. S., Johnson, C. E., Collins, W. J., Derwent, R. G., Shine, K. P., and Edwards, J. M.: Evolution of tropospheric ozone radiative forcing, Geophys. Res. Lett., 25, 3819-3822, 1998.

Stevenson, D. S., Collins, W. J., Johnson, C. E., and Derwent, R. G.: Intercomparison and evaluation of atmospheric transport in a Lagrangian model (STOCHEM), and an Eulerian model (UM), using ${ }^{222} \mathrm{Rn}$ as a short-lived tracer, Q. J. Roy. Meteor. Soc., 124, 2477-2491, 1998.

Stevenson, D. S., Johnson, C. E., Collins, W. J., Derwent, R. G., and Edwards, J. M.: Future estimates of tropospheric ozone radiative forcing and methane turnover - the impact of climate change, Geophys. Res. Lett. 27, 2073-2076, 2000.
Stevenson, D. S., Doherty, R. M., Sanderson, M. G., Johnson, C. E., Collins, W. J., and Derwent, R. G.: Impacts of climate change and variability on tropospheric ozone and its precursors, Faraday discuss., 130, 41-57, 2005.

Stevenson, D. S., Denterner, F. J., Schultz, M. G., et al.: Multimodel ensemble simulations of present-day and nearfuture tropospheric ozone, J. Geophys., Res., 111, D08301, doi:10.1029/2005JD006338, 2006.

Sudo, K., Takahashi, M., and Akimoto, H.: Future changes in stratosphere-troposphere exchange and their impacts on future tropospheric ozone simulations, Geophys. Res. Lett., 30, 2256, doi:10.1029/2003GL018526, 2003.

Thompson, A. M.:The oxidizing capacity of the Earth's atmosphere: Probable past and future changes, Science, 256, 11571164, 1992.

Valentin, K. M.: Numerical modeling of the climatological and anthropogenic influences on the chemical composition of the troposphere since the last glacial maximum, $\mathrm{Ph}$. D. thesis, University of Mainz, Germany, 1990.

van der Werf, G. R., Randerson, J. T., Collatz, G. J., and Giglio, L.: Carbon emissions from fires in tropical and subtropical ecosystems, Global Change biol., 9(4), 547-562, 2003.

Volz, A. and Kley, D.: Evaluation of the Montsouris series of ozone measurements made in the nineteenth century, Nature, 332, 240 242, 1988.

Wiedinmyer, C., Tie, X. X., Guenther, A., Neilson, R., and Granier, C.: Future changes in biogenic isoprene emissions: How might they affect regional and global atmospheric chemistry?, Earth Interactions, 10(3), 1-19, 2006.

Wu, S. L., Mickley, L. J., Jacob, D. J., Logan, J. A., Yantosca, R. M., and Rind, D.: Why are there large differences between models in global budgets of tropospheric ozone?, J. Geophys. Res., 112, D05302, doi:10.1029/2006JD007801, 2007.

Yienger, J. J. and Levy, H.: Empirical model of global soil-biogenic $\mathrm{NO}_{\mathrm{x}}$ emissions, J. Geophys. Res., 100, 11 447-11 464, 1995

Young, P. J.: The influence of biogenic isoprene emissions on atmospheric chemistry: A model study for present and future atmospheres, Ph. D. thesis, University of Cambridge, Cambridge, UK, 2007.

Zeng, G. and Pyle, J. A.: Changes in tropospheric ozone between 2000 and 2100 modeled in a chemistry-climate model, Geophys. Res. Lett., 30, 1392, doi:10.1029/2002GL016708, 2003.

Zeng, G. and Pyle, J. A.: Influence of El Niño southern oscillation on stratosphere/troposphere exchange and the global tropospheric ozone budget, Geophys, Res. Lett., 32, L01814, doi:10.1029/2004GL021353, 2005.

Zhang, L., Brook, J. R., and Vet, R.: A revised parameterization for gaseous dry deposition in air-quality models, Atmos. Chem. Phys., 3, 2067-2082, 2003, http://www.atmos-chem-phys.net/3/2067/2003/. 